\title{
Probiotics, prebiotics infant formula use in preterm or low birth weight infants: a systematic review
}

Mary N Mugambi ${ }^{1 *}$, Alfred Musekiwa ${ }^{2,3}$, Martani Lombard$^{1}$, Taryn Young ${ }^{3}$ and Reneé Blaauw ${ }^{1}$

\begin{abstract}
Background: Previous reviews (2005 to 2009) on preterm infants given probiotics or prebiotics with breast milk or mixed feeds focused on prevention of Necrotizing Enterocolitis, sepsis and diarrhea. This review assessed if probiotics, prebiotics led to improved growth and clinical outcomes in formula fed preterm infants.

Methods: Cochrane methodology was followed using randomized controlled trials (RCTs) which compared preterm formula containing probiotic(s) or prebiotic(s) to conventional preterm formula in preterm infants. The mean difference (MD) and corresponding 95\% confidence intervals (Cl) were reported for continuous outcomes, risk ratio (RR) and corresponding $95 \% \mathrm{Cl}$ for dichotomous outcomes. Heterogeneity was assessed by visual inspection of forest plots and a chi $\mathrm{i}^{2}$ test. An $\mathrm{I}^{2}$ test assessed inconsistencies across studies. $\mathrm{I}^{2}>50 \%$ represented substantial heterogeneity.

Results: Four probiotics studies ( $N=212), 4$ prebiotics studies $(N=126)$ were included. Probiotics: There were no significant differences in weight gain (MD 1.96, 95\% Cl: -2.64 to 6.56, 2 studies, $\mathrm{n}=34$ ) or in maximal enteral feed (MD 35.20, 95\% Cl: -7.61 to 78.02, 2 studies, $n=34$ ), number of stools per day increased significantly in probiotic group (MD 1.60, 95\% Cl: 1.20 to 2.00, 1 study, n=20). Prebiotics: Galacto-oligosaccharide / Fructo-oligosaccharide (GOS/FOS) yielded no significant difference in weight gain (MD 0.04, 95\% Cl: -2.65 to 2.73, 2 studies, $n=50$ ), GOS/FOS yielded no significant differences in length gain (MD 0.01, $95 \% \mathrm{Cl}:-0.03$ to $0.04,2$ studies, $\mathrm{n}=50$ ). There were no significant differences in head growth (MD $-0.01,95 \% \mathrm{Cl}$ : -0.02 to $0.00,2$ studies, $\mathrm{n}=76)$ or age at full enteral feed (MD $-0.79,95 \% \mathrm{Cl}:-2.20$ to $0.61,2$ studies, $n=86$ ). Stool frequency increased significantly in prebiotic group (MD 0.80, 95\% Cl: 0.48 to 1.1, 2 studies, $\mathrm{n}=86$ ). GOS/FOS and FOS yielded higher bifidobacteria counts in prebiotics group (MD 2.10, 95\% Cl: 0.96 to $3.24, n=27$ ) and (MD 0.48, 95\% Cl: 0.28 to $0.68, n=56$ ).
\end{abstract}

Conclusions: There is not enough evidence to state that supplementation with probiotics or prebiotics results in improved growth and clinical outcomes in exclusively formula fed preterm infants.

Keywords: Probiotic, Prebiotic, Preterm infant, Low birth weight infant

\section{Background}

Growth is a major challenge for premature and low birth weight infants (born $<37$ weeks gestation or with a birth weight of $<2500 \mathrm{~g}$ ). They have several factors that put them at risk for nutritional deficiencies resulting in poor growth. Decreased nutrient stores result in low body stores of glycogen, fat, protein, fat soluble vitamins, calcium, phosphorus, magnesium and trace minerals.

\footnotetext{
* Correspondence: nkmugambi@hotmail.com

${ }^{1}$ Division of Human Nutrition, Faculty of Medicine and Health Sciences, Stellenbosch University, P.O Box 19063, Tygerberg 7505, South Africa Full list of author information is available at the end of the article
}

Preterm infants require increased energy and nutrients for rapid growth and may need a 10 fold increase in weight gain in order to achieve optimum catch up growth $[1,2]$. To achieve optimum growth for the preterm infant, the goals are to continue the process of intra-uterine growth in an extra-uterine environment until 40 weeks post conception, foster catch-up growth and nutrient accumulation in the post discharge period [3-6]. A weight gain of 15 to $20 \mathrm{~g} / \mathrm{kg} /$ day, length of 0.75 to $1.0 \mathrm{~cm} /$ week and head circumference $0.75 \mathrm{~cm} /$ week is required. This is difficult to achieve and requires between $130-135 \mathrm{kcal} / \mathrm{kg} /$ day to maintain this growth

\section{Biomed Central}


rate [3]. Furthermore, infants lose weight after birth (up to $6 \%$ to $8 \%$ for extreme low birth weight infants) and they often do not regain the weight for up to 1 to 2 weeks [5]. Daily growth monitoring (weight gain, linear and head circumference) then becomes vital.

Preterm infants have immature physiological systems due to an underdeveloped gastrointestinal barrier function as reflected by increased intestinal permeability. As a result, potentially pathogenic bacteria translocate from the intestinal lumen and cause systemic infections [7]. Reducing intestinal permeability is associated with gut maturation which promotes growth and avoids severe infections [4]. In addition, digestive and absorptive capabilities are decreased due to low concentration of lactase, pancreatic lipase and bile salts. Gastrointestinal motility and stomach capacity are decreased which limits feeding volume and gastric emptying. A coordinated suck and swallow is not developed until 32 to 34 weeks gestation. Introduction of enteral feeding maybe delayed due to increased risk of aspiration $[1,2,8,9]$. Preterm infants in neonatal intensive care units (NICUs) develop a different intestinal microbiota compared to healthy breast fed infants. This is due to decreased exposure to the maternal microbiota, increased exposure to organisms that colonize NICUs, multiple courses of antibiotics and delays in feeding $[8,9]$.

Humans have consumed probiotics in the form of fermented food, dairy products and more recently infant and toddler formula. Probiotics are defined as "live microorganisms" which when administered in adequate amounts confer a health benefit to the host [10]. The main probiotic organisms used worldwide belong to the genera Lactobacillus and Bifidobacteria and are found in the gastrointestinal micro flora [10,11]. Prebiotics are found in fruit and vegetable components, they are nondigestible food ingredients that benefit the host by selectively stimulating the growth and/or activity of one or a limited number of bacteria in the colon and improving the host's health $[12,13]$. The most widely studied prebiotics are inulin, fructo-oligosaccharide (FOS) and galacto-oligosaccharide (GOS) which are plant storage carbohydrates in vegetables, cereals and fruit. FOS and inulin are added to different foods as fat and sugar replacements to improve texture or for their functional benefits [12,14-16]. Probiotics and prebiotics are added to infant formula to promote an intestinal microbiota resembling that of breastfed infants which have a greater concentration of bifidobacteria and less pathogenic bacteria than formula fed infants $[10,17]$.

There are a number of ways in which probiotics improve health. Health benefits conferred by probiotic bacteria are strain specific and not species or genus specific [10]. Probiotic bacteria improve health by affecting the immune system in different ways. They increase cytokine production such as Interleukin-6 (IL-6), Interferon- gamma (IFN- $\gamma$ ), Tissue Necrosis Factor alpha (TNF- $\alpha)$ Interleukin-1beta (IL-1 $\beta$ ) and Interleukin-10 (IL-10) [18]. Some strains increase phagocytic activity of peripheral blood leukocytes (monocytes, polymorphonuclear cells). Other strains strengthen the mucosal barrier function by promoting the production of mucosal antibodies and reducing the trans mucosal transfer of antigens. This reduces the intestinal permeability which in turn promotes growth [19-22]. Probiotics bacteria also enhance production of low molecular weight antibacterial substances produced by epithelial cells and production of short chain fatty acids, the main energy source for colonocytes. This maintains the integrity of colon mucosa [19,23-26].

Prebiotics are resistant to digestive enzymes and $\mathrm{pH}$ extremes found in the human gastrointestinal tract. They transit through the upper gastrointestinal tract and reach the colon intact where they are selectively fermented by indigenous bacteria, especially bifidobacteria and lactobacilli [12,15,26,27]. Beneficial bacteria (including bifidobacteria and lactobacilli) possess enzymes needed to metabolize prebiotics, while other bacteria (such as E coli, clostridia and salmonella) do not $[15,27]$. Consumption of prebiotics by preterm formula fed infants results in an increase of beneficial microorganisms in the colon, decreasing harmful bacteria to the levels found in breastfed infants. This improves the gastrointestinal mucosal barrier (decreasing intestinal permeability) which prevents infections and eventually results in improved growth $[27,28]$. In general the aim of adding probiotics and prebiotics to preterm infant formula is to improve growth, development and decrease infections by promoting an intestinal microbiota resembling that of breastfed infants $[9,29,30]$.

The effects of probiotics on the intestinal microbiota of premature infants have been varied due to differences on gestational age and products administered. Effects of probiotics on weight gain have also been varied. Administration of Bifidobacteria breve led to improved weight gain while Saccharomyces bourladii did not [9]. With premature infants optimal strains and dose regimens are yet to be examined closely [8]. The effects of prebiotics on the growth of premature infants are not clear. If prebiotic supplementation reduces the risk of Necrotizing Enterocolitis (NEC) or improves feed tolerance in very low birth weight infants is yet to be established [8,9]. Recent systematic reviews (published from 2005 to 2009) on the use of probiotics or prebiotics in preterm infants have focused on prevention of NEC and / or sepsis, impact on diarrhea [31-34]. These reviews focused on studies that used breast milk and mixed feeds (formula combined with breast milk). This review included infants given only infant formula and focused on growth with 
clinical outcomes that were not adequately addressed by previous reviews.

The Human Research Ethics Committee at the University of Stellenbosch, South Africa reviewed the review protocol (unpublished), ruled that all data to be collected for this review was from the public domain and was therefore exempt from ethical approval.

\section{Objective}

To assess if addition of probiotics or prebiotics to preterm infant formula led to improved growth and clinical outcomes in preterm or low birth weight infants.

\section{Methods}

\section{Eligibility criteria}

All randomized controlled trials (RCTs), irrespective of language, which compared the use of preterm infant formula containing probiotic(s) or prebiotic(s) to conventional preterm infant formula without or with placebo amongst preterm infants born $<37$ weeks gestation, low birth weight infants with $<2.5 \mathrm{~kg}$ at birth and hospitalized, receiving formula feeds and / or parenteral feed were considered. Studies published as abstracts were included if sufficient information could be obtained to assess study quality and obtain relevant study findings.

\section{Outcome measurements}

Primary outcomes included: Short term growth parameters (assessed for entire study duration approximately 4 weeks): weight gain (grams/day or grams/week), linear growth (centimeters/week), head growth (cm/week). Secondary outcomes included: Complications: Incidence of NEC (defined as suspected or confirmed positive Bell stage II or more), Sepsis (defined as signs or symptoms of infection and positive blood culture), Other infections (example bacteraemia defined as blood cultured positive for bacteria), Mortality / death. Adverse events during entire study duration: Number of days on parenteral, number of days to full enteral nutrition, maximal enteral feed (millilitres/day, millilitres/kilogram/day, millilitres /kilogram). Feed intolerance: Incidence of vomiting, gastric aspirates, abdominal distension. Stool characteristics: Stooling frequency and stool consistency as firm, loose or watery. Changes in intestinal permeability as measured by ratio of Lactulose / mannitol in urine or other sugar absorption tests (such as lactulose / L - rhamnose ratio, D- xylose, 3-O2- methyl-D- glucose tests). Gastrointestinal (GI) micro flora: number of colony forming units (cfu) of bifidobacteria, lactobacillus and pathogens post intervention).

\section{Search method for identification of studies}

A literature search in all languages was conducted on electronic databases which included The Cochrane

\section{Table 1 Search strategy used in PUBMED}

1) Search (probiotic* OR prebiotic*) AND (infant formula* OR infant feeding OR formula OR formula milk) AND (preterm or premature or low birth weight babies) AND (randomized controlled trial* OR controlled clinical trial* OR random allocation*) Limits: Human

2) Search (probiotic* infant formula* OR prebiotic* infant formula* OR prebiotic* OR probiotic ${ }^{*}$ ) AND (infant formula* OR infant feeding) AND (premature OR preterm) AND (randomized controlled trial* OR controlled clinical trial OR random allocation* OR double blind method OR single-blind method OR clinical trial OR placebo* OR random* OR research design OR comparative study OR follow-up studies OR prospectiv* OR volunteer* OR control* (singl* OR doubl* OR trebl* OR tripl*) NEAR (blind* OR mask*) Limits: Human

Central Register for Controlled Trials 2009, Scopus (1990 to 19/01/2010), EBSCO host (1960 to 15/11/ 2009), OVID (1950 to 01/12/2009), SPORT Discus (1960 to $19 / 01 / 2010)$, Web of Science (1970 to $19 / 01 / 2010)$, Science Direct (1950 to 30/11/2009), EMBASE (1980 to 01/12/2009), CINAHL (1981 to 19/01/2010), PUBMED / MEDLINE (1966 to 10/04/2010), Latin American Caribbean Health Sciences literature (LILACS), (1965 to 19/ 01/2010), NLM Gateway (1950-1966). RCTs published in non-English language journals were translated by independent translators who were familiar with the subject matter. The search strategy used to search PUBMED is shown on Table 1 . This search strategy was modified to search other electronic databases.

We conducted a hand search on abstracts of major conference proceedings such as the Pediatric Academic Society meetings (www.pas-meetings.org, www.abstracts2view.com), cross checked references cited in RCTs and in recent reviews (published from 2005 to 2009) for additional studies not identified by electronic searches and specialty journals which were not included in any database such as Pediatrika, Chinese Journal of Microecology and International Journal of Probiotics and Prebiotics.

To identify on-going and unpublished trials, we contacted experts in the field, manufacturers of infant formula containing probiotics and prebiotics, we searched web sites of companies that have conducted or were conducting RCTs on probiotics and prebiotics e.g. Pfizer (www.pfizerpro.com/clinicaltrials), Chris Hansen Laboratory (www.chr-hansen.com/research_development/ documentation.html). We also searched prospective trial registries such as World Health Organisation (WHO) International Clinical Trials Registry Platform Search Portal (www.who.int/trialsearch), Clinical Trials.gov register (www.clinicaltrials.gov), Current Controlled Trials meta Register of Controlled Trials [mRCT] (www.controlledtrials.com/mrct) and www.clinicaltrialresults.org.

\section{Selection of studies}

Two reviewers (MM, ML) independently reviewed all abstracts, citations and identified potentially eligible 
studies. The full reports of eligible studies were retrieved by one reviewer (MM) and the pre-specified selection criteria applied independently by two reviewers (MM, ML) using a study eligibility form. (Figure 1) If more than one publication of a study existed, all reports of the study were grouped together under one study name. Any disagreements between the reviewers were resolved through discussion. If disagreements could not be resolved a third party was consulted. Trial authors were contacted if eligibility was unclear.

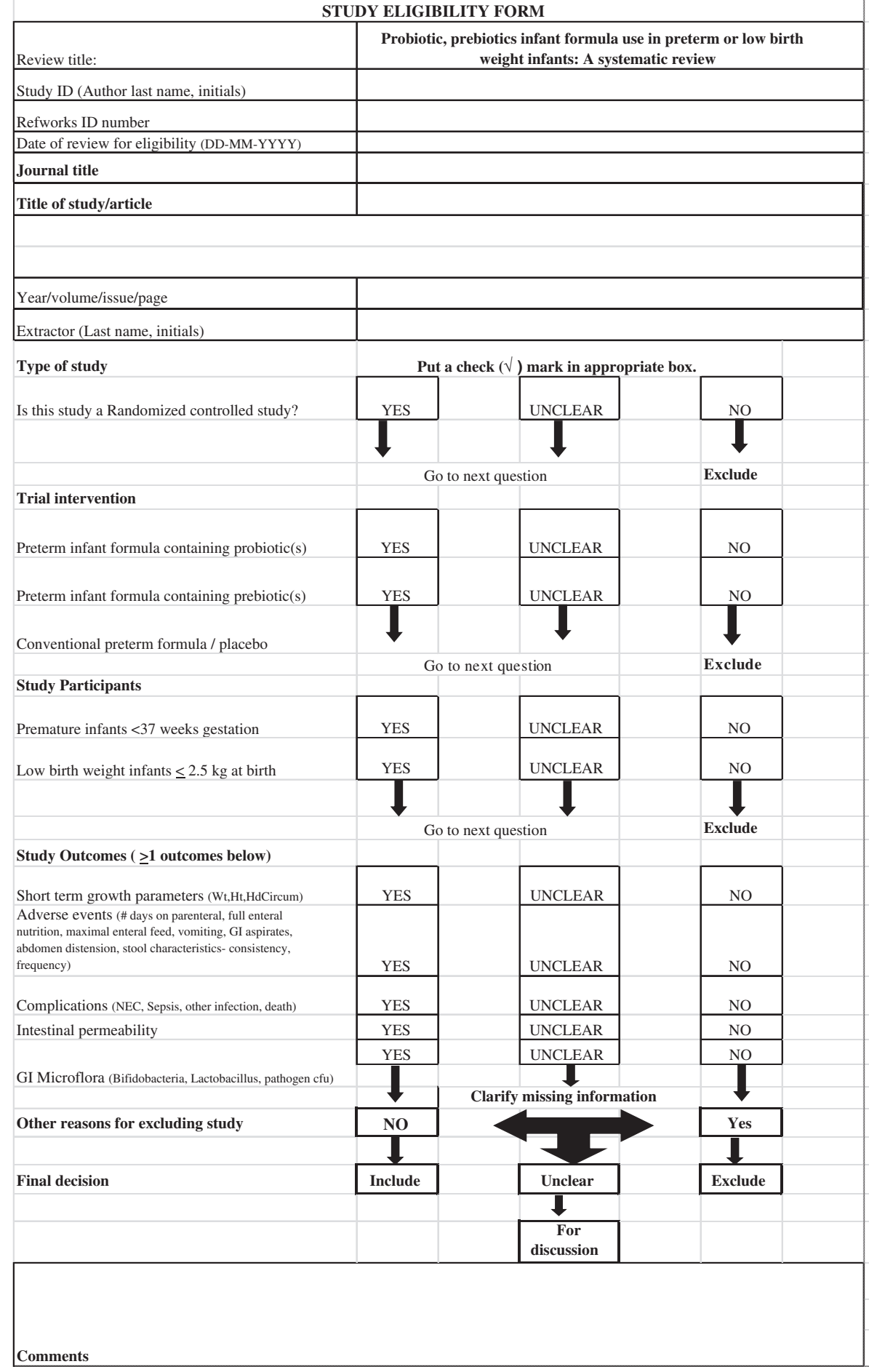

Figure 1 Study eligibility form. 


\section{Assessment of quality of evidence}

Two reviewers (MM, ML) independently assessed the risk of bias of included studies as described in the Cochrane Handbook for Systematic Reviews for Interventions according to the following 6 components. 1) sequence generation; 2) allocation concealment; 3) blinding; 4) incomplete outcome data; 5) selective outcome reporting; and 6) other sources of bias [35]. Where necessary, trial authors were contacted for clarification on the methodology of their studies. Any disagreements regarding risk of bias were resolved through discussion between MM, ML and RB.

\section{Data extraction and management}

Two reviewers (MM, ML) independently extracted data using a pre tested data extraction form. The reviewers (MM, ML) cross checked data and resolved any differences through discussion. One reviewer (MM) entered the data in Review Manager (RevMan 5) and the other reviewer (ML) validated the data. Trial authors were contacted for missing data or for clarification.

\section{Data synthesis and management}

Results for probiotic and prebiotic studies were analysed separately. For continuous outcomes the mean difference (MD) and corresponding 95\% confidence intervals (CI) were calculated. For dichotomous outcomes, the risk ratio (RR) and corresponding 95\% CI were calculated. Trial authors were contacted if there was missing data in their reports. Available case analysis was used where there was missing data. The potential impact of the missing data on the results of the review is addressed in the discussion section. Heterogeneity of the trials used in the review was assessed by visually inspecting the forest plots to detect overlapping confidence intervals and by performing a chi ${ }^{2}$ test. A $\mathrm{p}<0.1$ was considered statistically significant. An I-square test $\left(\mathrm{I}^{2}\right)$ was used to test for inconsistencies across studies. If the $\mathrm{I}^{2}$ exceeded $50 \%$ and visual inspection of the forest plot supported these results, this represented substantial heterogeneity.

If the included studies were not clinically diverse and had similar outcome measures, a Meta - analysis was carried out in Review Manager software (RevMan 5) by one review author (AM). For continuous data, if heterogeneity was low, an inverse variance fixed-effect method was used. If heterogeneity was high, an inverse variance random-effects method was used. For dichotomous data, if heterogeneity was low, a Mantel-Haenszel fixed-effects method was used. If heterogeneity was high, a MantelHaenszel random-effects method was used. The source of heterogeneity was explored through subgroup analysis with respect to the type of intervention. If studies were too diverse, no Meta-analysis was conducted and a narrative synthesis was provided. We had intended to perform sensitivity analysis with respect to study quality in order to investigate the robustness of our findings but this could not be done mainly because most of the meta-analysis had too few studies (mostly two) to warrant sensitivity analysis. In some cases, all the studies in the meta-analysis had similar study quality thus rendering sensitivity analysis inappropriate.

\section{Results}

\section{Results of the search and description of studies}

Electronic search of available databases yielded 151 citations. After reading titles, abstracts, the duplicate reports were removed and 35 potentially relevant articles were identified. A hand search yielded 4 more articles. The full text reports were retrieved and reviewed for eligibility. One study was published in two other reports. The three studies were considered as one study since they reported the same identical study and are referred to as Boehm 2002 in this review [36-38]. Eight published

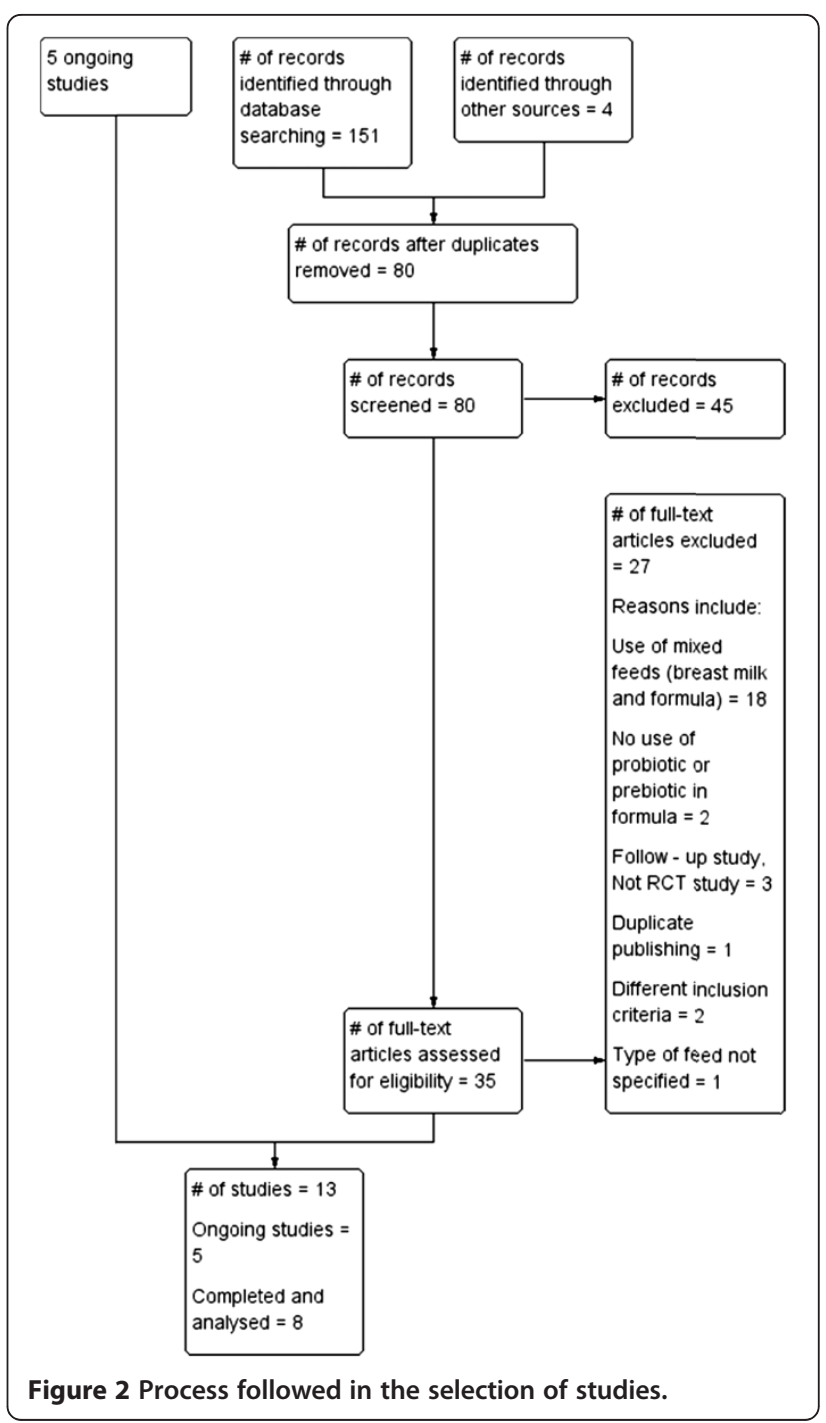


Table 2 Excluded studies with reasons for exclusion

\begin{tabular}{|c|c|c|c|c|c|c|c|}
\hline \multicolumn{8}{|c|}{ Reasons for exclusion of studies } \\
\hline \multicolumn{3}{|c|}{$\begin{array}{l}\text { Use of breast milk or mixed feeds } \\
\text { (breast milk and formula) }\end{array}$} & \multirow{2}{*}{$\begin{array}{l}\begin{array}{l}\text { No use of } \\
\text { probiotic, } \\
\text { prebiotic }\end{array} \\
\text { Andrews } 1969 \text { [55] }\end{array}$} & \multirow{2}{*}{$\begin{array}{l}\text { Follow up - } \\
\text { study, } \\
\text { Not RCT } \\
\text { Chou I-C } 2009 \text { [56] }\end{array}$} & \multirow{2}{*}{$\begin{array}{l}\begin{array}{l}\text { Duplicate } \\
\text { publishing }\end{array} \\
\begin{array}{l}\text { Stansbridge } \\
1993 \text { [57] }\end{array}\end{array}$} & \multirow{2}{*}{$\begin{array}{l}\text { Different } \\
\text { inclusion criteria } \\
\text { and outcomes }\end{array}$} & \multirow{2}{*}{$\begin{array}{l}\text { Type of feed } \\
\text { unspecified }\end{array}$} \\
\hline Agarwal 2003 [52] & Lin H-C 2008 [53] & Riskin 2009 [54] & & & & & \\
\hline Bin-Nun 2005 [59] & Manzoni 2006 [60] & Rouge 2009 [61] & Taylor 2009 [62] & Hoyos 1999 [63] & & Wang 2007 [64] & \\
\hline Dani 2002 [65] & Millar 1993 [66] & Samanta 2005 [67] & & Lidesteri 2003 [68] & & & \\
\hline Kitajima 1997 [69] & Mohan 2006 [70] & Westerbeek 2008 [71] & & & & & \\
\hline Lee 2007 [72] & Mohan 2008 [73] & Westerbeek 2010 [74] & & & & & \\
\hline Lin H-C 2005 [75] & Patole 2005 [76] & Yong Gu 2009 [77] & & & & & \\
\hline
\end{tabular}

studies (four probiotic and four prebiotic studies) [36,39-45] and five on-going studies were included in this review [46-51]. The process followed is shown in Figure 2. Table 2 gives a list of 27 studies which were excluded for: use of breast milk or mixed feeds (18 studies), no use of probiotic or prebiotic ( 2 studies), being a follow -up study, not RCT (3 studies), duplicate publishing (1 study); using different inclusion criteria with

Table 3 A summary of four included probiotic studies

\begin{tabular}{|c|c|c|c|c|}
\hline & Costalos 2003 [39] & Indrio 2008 [42] & Reuman 1986 [41] & Stratiki 2007 [40] \\
\hline Location of study & Athens, Greece & $\begin{array}{l}\text { University of Bari, } \\
\text { Policinico, Italy }\end{array}$ & Gainesville, Florida, USA & $\begin{array}{l}\text { Alexandra Regional } \\
\text { Hospital, Greece }\end{array}$ \\
\hline $\begin{array}{l}\text { Participants - } \\
\text { inclusion criteria }\end{array}$ & 28 - 32 weeks gestation & $\begin{array}{l}\text { 3- } 5 \text { days old, appropriate } \\
\text { for gestational age, } \\
\text { preterm infants with } \\
\text { normal agpar scores }\end{array}$ & $\begin{array}{l}\text { Premature infants, } \\
<2000 \mathrm{~g} \text { at birth, } \\
\text { less than } 72 \text { hours old } \\
\text { (>24 old to }<72 \text { hours old) }\end{array}$ & $\begin{array}{l}27 \text { to } 37 \text { weeks gestation, } \\
\text { in stable state }\end{array}$ \\
\hline $\begin{array}{l}\text { Number of study } \\
\text { participants }\end{array}$ & $\begin{array}{l}\text { Study group }=51 \\
\text { Placebo }=36\end{array}$ & $\begin{array}{l}\text { Study group }=10 \\
\text { Placebo }=10\end{array}$ & $\begin{array}{l}\text { Study group }=15 \\
\text { Placebo }=15\end{array}$ & $\begin{array}{l}\text { Study group }=41 \\
\text { Placebo }=34\end{array}$ \\
\hline Probiotic bacteria used & Saccharomyces Bourlardii & $\begin{array}{l}\text { Lactobacillus Reuteri } \\
\text { ATCC } 55730\end{array}$ & Lactobacillus acidophilus & Bifidobacteriumlactis \\
\hline Dose of probiotic & $\begin{array}{l}10^{9} \mathrm{cfu} \text { at } 50 \mathrm{mg} / \mathrm{kg} \\
\text { every } 12 \text { hours }\end{array}$ & $1 \times 10^{8} \mathrm{cfu} /$ day & $9 \times 10^{6} \mathrm{cfu} / \mathrm{ml}$ formula & $2 \times 10^{7} \mathrm{cfu} / \mathrm{g}$ milk powder \\
\hline Placebo & Maltodextrin & $\begin{array}{l}\text { Indistinguishable } \\
\text { placebo }\end{array}$ & $\begin{array}{l}\text { Conventional } \\
\text { preterm formula }\end{array}$ & $\begin{array}{l}\text { Conventional } \\
\text { preterm formula }\end{array}$ \\
\hline Dose of placebo & 50 mg / kg / 12 hours & Not reported & & \\
\hline Treatment initiation & $\begin{array}{l}\text { 1st week of life as soon as } \\
\text { enteral feed was tolerated }\end{array}$ & At 3-5 days of life & 1st 72 hours of life & 1st 2 days of life \\
\hline Treatment duration & 30 days & 30 days & Not specified & 30 days \\
\hline \multicolumn{5}{|l|}{ Reported Outcomes } \\
\hline Growth parameters & Weight gain & Weight gain & Weight gain & $\begin{array}{l}\text { Weight gain, Linear growth, } \\
\text { Head circumference }\end{array}$ \\
\hline $\begin{array}{l}\text { Timing and duration of } \\
\text { measurement of } \\
\text { growth parameters }\end{array}$ & $\begin{array}{l}\text { Measured daily } \\
\text { for } 30 \text { days }\end{array}$ & $\begin{array}{l}\text { Measured daily } \\
\text { for } 30 \text { days }\end{array}$ & $\begin{array}{l}\text { Measured daily, } \\
\text { duration not specified }\end{array}$ & $\begin{array}{l}\text { Weight gain: measured daily, } \\
\text { Lineargrowth (measured weekly), } \\
\text { Head circumference } \\
\text { (measured weekly) }\end{array}$ \\
\hline Feed tolerance & $\begin{array}{l}\text { Number of days to } \\
\text { full enteral feed, } \\
\text { Maximal enteral } \\
\text { feed, vomiting }\end{array}$ & $\begin{array}{l}\text { Number of days to } \\
\text { full enteral feed, } \\
\text { Maximal enteral } \\
\text { feed, vomiting }\end{array}$ & Maximal enteral feed & $\begin{array}{l}\text { Number of days to } \\
\text { full enteral feed, } \\
\text { Maximal enteral feed }\end{array}$ \\
\hline Stool characteristics & & Stooling frequency & & \\
\hline Complications & NEC, Sepsis & & Mortality / death & NEC, Sepsis \\
\hline Intestinal permeability & $\begin{array}{l}\text { Changes in Intestinal } \\
\text { permeability }\end{array}$ & & & $\begin{array}{l}\text { Changes in Intestinal } \\
\text { permeability }\end{array}$ \\
\hline $\begin{array}{l}\text { Changes in } \\
\text { gastrointestinal microflora }\end{array}$ & $\begin{array}{l}\text { cfu of bifidobacteria, } \\
\text { lactobacillus, pathogens }\end{array}$ & & & cfu of bifidobacteria \\
\hline
\end{tabular}


different outcomes (2 studies) and type of feed was unspecified (1 study). No eligible studies were excluded for failure to report the review's pre-specified outcomes.

A summary of the included probiotic, prebiotic and on-going studies are shown in Tables 3, 4 and 5. The included probiotic studies $(\mathrm{N}=212)$ were conducted in Greece, Italy and United States of America (USA). Treatment duration was 30 days using different probiotics. All four probiotic studies reported short term growth parameters (weight gain) which were recorded daily during the entire study duration [Table 3]. None of the probiotic studies reported data on: other types of infections, use of parenteral nutrition, feed intolerance (gastric aspirate $[\mathrm{ml}]$, abdominal distension) and stool consistency. The included prebiotic studies $(\mathrm{N}=126)$ were conducted in conducted in Greece, Italy, and Germany. Treatment duration ranged from 14 days to 28 days. All four prebiotic studies reported short term growth parameters (weight gain, length, head growth) which were recorded at different intervals during the entire study duration [Table 4]. None of the prebiotic studies reported data on: complications (NEC, sepsis, other types of infections, death / mortality), use of parenteral nutrition, feed intolerance (vomiting, gastric aspirate [ml], abdominal distension) and changes in intestinal permeability.

\section{Risk of bias}

The quality of the included studies was assessed across six domains using guidelines from the Cochrane Handbook for Systematic Reviews of Interventions [35] (Figure 3).

Random sequence generation: Three trials described clearly the methods used for random sequence generation $[40,41,44]$. Mihatsch used computer generated random lists with variable block sizes [44]. Stratiki used balance block randomization using random numbers [40] and Reuman used random numbers list combined with the last digit of the patients' medical record [41]. The method used for random sequence generation was not clearly described 5 studies [36,39,42,43,45].

Allocation Concealment: In two trials treatment allocation was adequately concealed $[33,40]$. In the Stratiki trial, treatment allocation was conducted by a third party who was not involved in the study (Nutritional service) [40]. Mihatsch used precoded sachets in sealed envelopes [44]. In one study treatment allocation was not adequately concealed because the method used was

Table 4 A summary of four included prebiotic studies

\begin{tabular}{|c|c|c|c|c|}
\hline & Boehm 2002 [36] & Indrio 2009 [43] & Kapiki 2007 [45] & Mihatsch 2006 [44] \\
\hline Location of study & Milan, Italy & $\begin{array}{l}\text { University of Bari, } \\
\text { Policinico, Italy }\end{array}$ & Athens, Greece & Ulm University, Germany \\
\hline Participants - entry criteria & $<32$ weeks gestation & Healthy preterm newborns & $\leq 36$ weeks gestation & $<1500 \mathrm{~g}$ birth weight \\
\hline Number of study participants & $\begin{array}{l}\text { Study group = 15, } \\
\text { Placebo }=15\end{array}$ & $\begin{array}{l}\text { Study group }=10 \\
\text { Placebo }=10\end{array}$ & $\begin{array}{l}\text { Study group = 36, } \\
\text { Placebo }=20\end{array}$ & $\begin{array}{l}\text { Study group }=10 \\
\text { Placebo }=10\end{array}$ \\
\hline Prebiotic used & GOS $90 \%$, FOS $10 \%$ & scGOS, IcFOS at ratio 9:1 & FOS & GOS, FOS \\
\hline Dose of prebiotic & $1 \mathrm{~g} / \mathrm{dl}$ & $0.8 \mathrm{~g} / \mathrm{dl}$ & $0.4 \mathrm{~g} / 100 \mathrm{ml}$ & $1 \mathrm{~g} / \mathrm{dl}$ \\
\hline Placebo & Maltodextrin & Maltodextrin & Maltodextrin & Maltodextrin \\
\hline Dose of placebo & $1 \mathrm{~g} / \mathrm{dl}$ & $0.8 \mathrm{~g} / \mathrm{dl}$ & $0.4 \mathrm{~g}$ & $1.8 / 90 \mathrm{ml}$ \\
\hline Treatment initiation & $\begin{array}{l}\text { When enteral feed } \geq \\
80 \mathrm{mls} / \mathrm{kg} / \text { day was tolerated }\end{array}$ & Not clear & $\begin{array}{l}\text { Exclusively formula } \\
\text { fed at start of study }\end{array}$ & $\begin{array}{l}\text { At full enteral feed at } \\
\text { start of study }\end{array}$ \\
\hline Treatment duration & 28 days & 15 days & 14 days & 15 days \\
\hline \multicolumn{5}{|l|}{ Reported Outcomes } \\
\hline Growth parameters & Weight gain, linear growth & $\begin{array}{l}\text { Weight gain, linear growth, } \\
\text { head growth }\end{array}$ & $\begin{array}{l}\text { Weight gain, linear growth, } \\
\text { head growth }\end{array}$ & Weight gain \\
\hline $\begin{array}{l}\text { Timing and duration of } \\
\text { measurement of } \\
\text { growth parameters }\end{array}$ & Measured on days $1,7,14,28$ & $\begin{array}{l}\text { Measured before start of } \\
\text { study, days } 3,5,15\end{array}$ & Measured on days $1,7,14$ & $\begin{array}{l}\text { Weight gain: reported as } \\
\text { "Average weight } \\
\text { gain during study." }\end{array}$ \\
\hline Feed tolerance & $\begin{array}{l}\text { Number of days to full enteral } \\
\text { feed, maximal enteral feed }\end{array}$ & $\begin{array}{l}\text { Number of days to } \\
\text { full enteral feed, } \\
\text { maximal enteral feed }\end{array}$ & $\begin{array}{l}\text { Number of days to } \\
\text { full enteral feed }\end{array}$ & $\begin{array}{l}\text { Number of days to } \\
\text { full enteral feed, } \\
\text { maximal enteral feed }\end{array}$ \\
\hline Stool characteristics & $\begin{array}{l}\text { Stooling frequency, } \\
\text { consistency }\end{array}$ & & $\begin{array}{l}\text { Stooling frequency, } \\
\text { consistency }\end{array}$ & $\begin{array}{l}\text { Stool viscosity, } \\
\text { Stooling frequency, } \\
\text { consistency }\end{array}$ \\
\hline $\begin{array}{l}\text { Changes in gastrointestinal } \\
\text { microflora }\end{array}$ & cfu bifidobacteria & & $\begin{array}{l}\text { cfu bifidobacteria, } \\
\text { pathogens }\end{array}$ & \\
\hline
\end{tabular}


Table 5 A summary of five on-going studies

\begin{tabular}{|c|c|c|c|c|c|}
\hline & Jacobs 2007 [46] & Lozano 2008 [47] & Al-Hosni 2010 [48] & Patole 2009 [49] & Underwood 2009 [50] \\
\hline Location of study & Australia & Colombia & USA & Australia & USA \\
\hline $\begin{array}{l}\text { Participants - } \\
\text { inclusion } \\
\text { criteria }\end{array}$ & $\begin{array}{l}<32 \text { weeks gestation, } \\
<1500 \mathrm{~g} \text { birth weight, } \\
1-3 \text { days old }\end{array}$ & $\begin{array}{l}\text { Birth weight } \\
<2000 \text { grams, } \\
<48 \text { hours of age, } \\
\text { admission in NICU, } \\
\text { Hemodynamic-ally } \\
\text { stable }\end{array}$ & $\begin{array}{l}\text { Extremely Low Birth } \\
\text { weight infants: } \\
\text { < } 1000 \text { grams, } \\
1 \text { to } 14 \text { old, } \\
\text { intention to s } \\
\text { tart enteral feeds }\end{array}$ & $\begin{array}{l}32 \text { weeks Gestation } \\
\text { and } 6 \text { days, } \\
<1500 \mathrm{~g} \text { birth weight, } \\
\text { ready to commence } \\
\text { on enteral feeds } \\
\text { for up to } 12 \text { hours }\end{array}$ & $\begin{array}{l}<500 \text { grams birth weight, } \\
\text { age less than } 33 \text { weeks } \\
\text { gestation, exclusively } \\
\text { formula fed }\end{array}$ \\
\hline \multirow{4}{*}{$\begin{array}{l}\text { Probiotic } \\
\text { bacteria used }\end{array}$} & \multirow{4}{*}{$\begin{array}{l}\text { Bifidobacteriuminfantis, } \\
\text { BifidobacteriumBifidus, } \\
\text { Streptococcus } \\
\text { thermophilus }\end{array}$} & \multirow{4}{*}{$\begin{array}{l}\text { Lactobacillus reuteri } \\
\text { DSM } 17938\end{array}$} & \multirow{4}{*}{$\begin{array}{l}\text { Lactobacillus rhamnosus } \\
\text { GG, Bifidobacteriuminfantis }\end{array}$} & \multirow{4}{*}{$\begin{array}{l}\text { Lactobacillus acidophilus } \\
375 \text { million, } \\
\text { bifidobacteriumbifidum, } \\
\text { bifidobacteria longus }\end{array}$} & 1. ProlactPlus \\
\hline & & & & & 2. GOS \\
\hline & & & & & 3. Bifidobacteriuminfantis \\
\hline & & & & & 4. Bifidobacteriumanimalis \\
\hline \multirow[t]{4}{*}{ Dose } & \multirow[t]{4}{*}{$1 \times 10^{9}$} & \multirow{4}{*}{$\begin{array}{l}1 \times 108 \text { CFU in } 5 \\
\text { drops of oil } \\
\text { suspension } \\
1 / \text { day until } \\
\text { discharge. }\end{array}$} & \multirow{4}{*}{$\begin{array}{l}\text { L rhamnosus: } \\
500 \text { million cfu, } \\
\text { B.infantis: } \\
500 \text { million cfu }\end{array}$} & \multirow{4}{*}{$\begin{array}{l}\text { L. acidophilus: } 375 \mathrm{~m} \\
\text { organisms, B bifidum, } \\
\text { B. longus: } \\
125 \text { million organisms }\end{array}$} & $\begin{array}{l}\text { 1. week } 195: 5 \\
\text { to week } 5 \text { 75:25 }\end{array}$ \\
\hline & & & & & $\begin{array}{l}\text { 2. week: } 0.25 \mathrm{~g} / \mathrm{dL} \text {, } \\
\text { to week } 5: 2.0 \mathrm{~g} / \mathrm{dL}\end{array}$ \\
\hline & & & & & $\begin{array}{l}\text { 3. week 1: } 5 \times 10^{7}, \\
\text { to week 5: } 4.2 \times 10^{9}\end{array}$ \\
\hline & & & & & $\begin{array}{l}\text { 4. week 1: } 5 \times 10^{7} \\
\text { to week 5: } 4.2 \times 10^{9}\end{array}$ \\
\hline $\begin{array}{l}\text { Start date of } \\
\text { study }\end{array}$ & July- 2007 & August 2008 & February 2008 & June 2009 & June 2009 \\
\hline \multirow{7}{*}{$\begin{array}{l}\text { Reported } \\
\text { Outcomes }\end{array}$} & Sepsis, & Sepsis & Average weight gain & Sepsis & Fecal microflora \\
\hline & NEC & NEC & Growth velocity & NEC & \\
\hline & Death & Death & Feed tolerance & All-cause mortality & \\
\hline & Frequency of events & & Volume of feed/day & $\begin{array}{l}\text { Time to reach full feeds } \\
(150 \mathrm{mls} / \mathrm{kg} / \text { day })\end{array}$ & \\
\hline & $\begin{array}{l}\text { Length of } \\
\text { hospital admission }\end{array}$ & & & $\begin{array}{l}\text { Gut colonisation } \\
\text { by probiotic }\end{array}$ & \\
\hline & $\begin{array}{l}\text { Number of } \\
\text { antibiotic courses }\end{array}$ & & & & \\
\hline & $\begin{array}{l}\text { Days to } f \\
\text { ull enteral feeds }\end{array}$ & & & & \\
\hline
\end{tabular}

alternation, matching of infants by birth weight and gestational age [41]. In the rest of the studies, allocation concealment was not clearly demonstrated or described $[36,39,42,43]$.

Blinding: Blinding of study participants, care providers and assessors was clearly done in 4 trials [39-41,44]. In the other 4 trials, there was not enough information given on the blinding method to make a judgement $[36,42,43,45]$.

Incomplete outcome data: Reported outcome data was satisfactory for all the eight included studies. Five studies had no missing outcome data [36,41-44]. In other three studies, the missing outcome data was balanced across the intervention groups with similar reasons reported $[39,40,45]$.

Selective reporting (reporting bias): In all eight studies, the pre-specified outcomes in the methods section were reported in the results section [36,39-45].
Other potential sources of bias: Only one trial had a baseline imbalance which was a potential source of bias. Costalos had 51 infants enrolled in the treatment group and 36 infants in the placebo group. No explanation was presented whether the imbalance was due to a problem at randomization stage [39]. All other studies appeared to be free from other potential sources of bias.

\section{Effects of interventions}

Probiotics versus control

Four studies investigated the effect of probiotic administration versus no probiotic (control group) [39-42].

\section{Primary outcomes: short term growth parameters}

Weight gain All four studies reported on weight gain [39-42]. Results from two studies $(n=34)$ were pooled in a meta-analysis $[41,42]$. There was no statistically 
Two studies $[39,40]$ reported their results using medians and could not be pooled in a meta - analysis. Costalos 2003 reported no statistically significant difference in weight gain (g/week) between the probiotic and control groups ( $>00.05)$ [median (Interquartile range) of 163.5 (17.7) for the probiotic group $(n=51)$ compared to 155.8 (16.5) for the control group $(n=36)$ ] [39]. Stratiki 2007 also reported no statistically significant difference in weight gain (g/day) between the probiotic and control groups $(\mathrm{p}=0.144)$ [median (range) of 28.3 (12 to 38) for the probiotic group $(n=41)$ compared to 30 (10 to 40$)$ for the control group $(n=34)]$ [40].

Linear growth Only one study reported this outcome but found no statistically significant difference in length gain ( $\mathrm{cm} /$ week) between the probiotic and control groups $(\mathrm{p}=0.124)$ [median (range) of 1.4 (0 to 3 ) for the probiotic group $(n=41)$ compared to 1.5 (0 to 3.5$)$ for the control group $(n=34)$ ] [40].

Head growth Only one study reported this outcome but found no statistically significant difference in head growth ( $\mathrm{cm} /$ week) between the probiotic and control groups $(\mathrm{p}=0.124)$ [median (range) of 1.1 (0.45 to 1.9) for the probiotic group $(n=41)$ compared to 0.9 (0 to 2$)$ for the control group $(n=34)]$ [40].

\section{Secondary outcomes Complications}

Necrotizing enterocolitis [NEC] Two studies $(n=162)$ reported on NEC and their results were pooled in a meta-analysis $[39,40]$. Administration of probiotics failed to significantly reduce the risk of NEC compared to controls (RR 0.42, 95\% CI: 0.15 to 1.16 ). No significant heterogeneity was observed $\left(\mathrm{Chi}^{2}=1.06, \mathrm{p}=0.30, \mathrm{I}^{2}=6 \%\right)$ (Figure 5).

Figure 3 Methodological quality of included studies.

significant difference in weight gain (g/day) between the probiotic and control groups (MD 1.96, 95\% CI: -2.64 to 6.56). No statistically significant heterogeneity was observed $\left(\mathrm{Chi}^{2}=0.18, \mathrm{p}=0.67, \mathrm{I}^{2}=0 \%\right)$ (Figure 4 )

Sepsis Two studies $(n=162)$ reported on sepsis and their results were pooled in a meta-analysis $[39,40]$. Administration of probiotics failed to significantly reduce the risk of sepsis compared to controls (RR 0.40, 95\% CI: 0.11 to 1.45. No significant heterogeneity was observed $\left(\mathrm{Chi}^{2}=1.18, \mathrm{p}=0.28, \mathrm{I}^{2}=15 \%\right)$. (Figure 6)

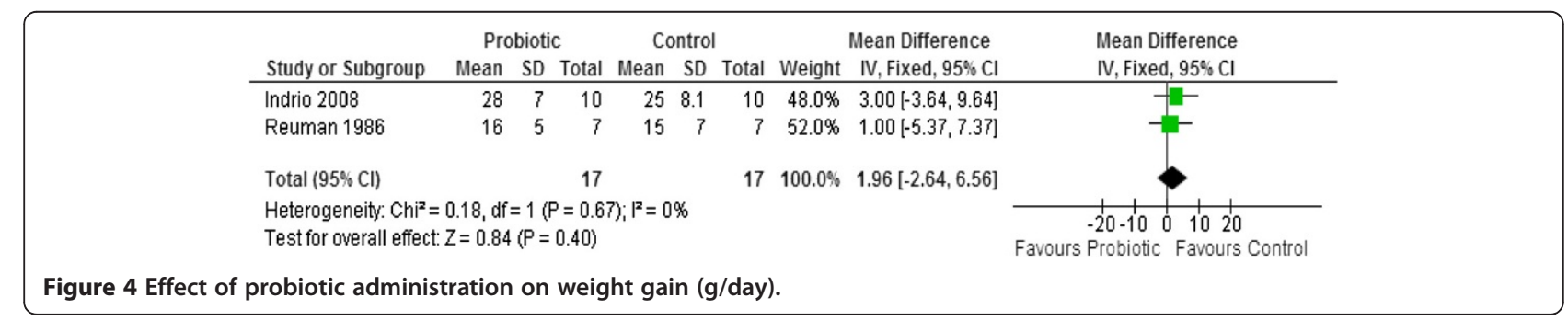




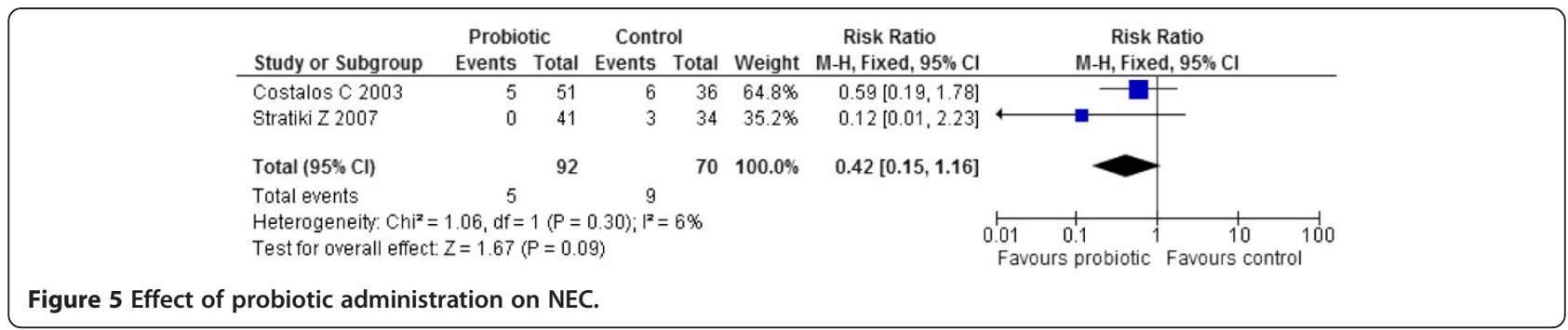

Other infections No study reported on this outcome.

Mortality Only one study [42] reported on mortality. The risk ratio for this one study $(n=30)$ was calculated and it showed that the probiotics failed to significantly reduce the risk of death compared to the control (RR 0.33, $95 \%$ CI: 0.04 to 2.85 ).

Number of days on parenteral nutrition No study reported on this outcome.

Number of days to full enteral feed Two studies reported this outcome but their results could not be pooled in a meta-analysis because they reported the outcome in terms of medians and ranges $[39,40]$. Costalos 2003 reported no statistically significant difference in the number of days to full enteral feeding between the two groups ( $\mathrm{p}>0.1$ ) [median (IQR) of 9.3 (2.7) for the probiotic group $(n=51)$ and 9.9 (4.5) for the control group $(n=36)$ ] [32]. Stratiki 2007 also reported no statistically significant difference in the number of days to full enteral feeding [median (range) of 10 (0 to 52) for the probiotic group $(n=41)$ and $10(0$ to 30$)$ for the control group $(n=34)][40]$.

Maximal enteral feed All four studies reported on this outcome [39-42]. Results from two studies $(n=34)$ were pooled in a meta-analysis as they both reported the average amount of feeding (ml/day) in terms of mean (SD) $[41,42]$. There was no statistically significant difference in the mean amount of feeding ( $\mathrm{ml} /$ day) between the probiotic and control groups (MD 35.20, 95\% CI: -7.61 to
78.02) No statistically significant heterogeneity was observed between the studies $\left(\mathrm{Chi}^{2}=1.65, \mathrm{p}=0.20, \mathrm{I}^{2}=39 \%\right)$.

Costalos 2003 reported no statistically significant difference in the milk intake $(\mathrm{ml} / \mathrm{kg} /$ day $)$ at maximal enteral feeding ( $p>0.1)$ [median (IQR) of 155 (15) for the probiotic group $(\mathrm{n}=51)$ versus 148 (13) for the control group $(n=36)$ ] [39]. Stratiki 2007 also reported no statistically significant difference in the maximal milk intake $(\mathrm{ml} / \mathrm{kg} /$ day) $(\mathrm{p}=0.624)$ [median (range) of 210 (165 to $250)$ for the probiotic $(n=41)$ group versus 192 (120 to $250)$ for the control group $(n=34)$ ] [40].

Feed tolerance: vomiting, gastric aspirate, abdominal distension Two studies $(n=107)$ reported on vomiting and were pooled in a meta-analysis $[39,42]$. There was no statistically significant difference in the frequency of vomiting between the probiotic and control groups (RR $0.78,95 \% \mathrm{CI}: 0.18$ to 3.37$)$. No statistically significant heterogeneity was observed $\left(\mathrm{Chi}^{2}=0.41, \mathrm{p}=0.52, \mathrm{I}^{2}=0 \%\right)$.

In all four probiotic studies, there were no reported incidences of gastric aspirates, abdominal distension or diarrhea. Authors were further contacted for clarification and one responded [42] and stated categorically that none of these symptoms were observed.

\section{Stool characteristics}

Stool frequency Only one study $(n=20)$ reported stool frequency as the number of episodes of evacuations per day in terms of mean (SD) [42]. The mean difference for this one study was calculated and it showed that probiotic consumption resulted in a statistically significant larger number of stools per day compared to the control group (MD 1.60, 95\% CI: 1.20 to 2.00 ).

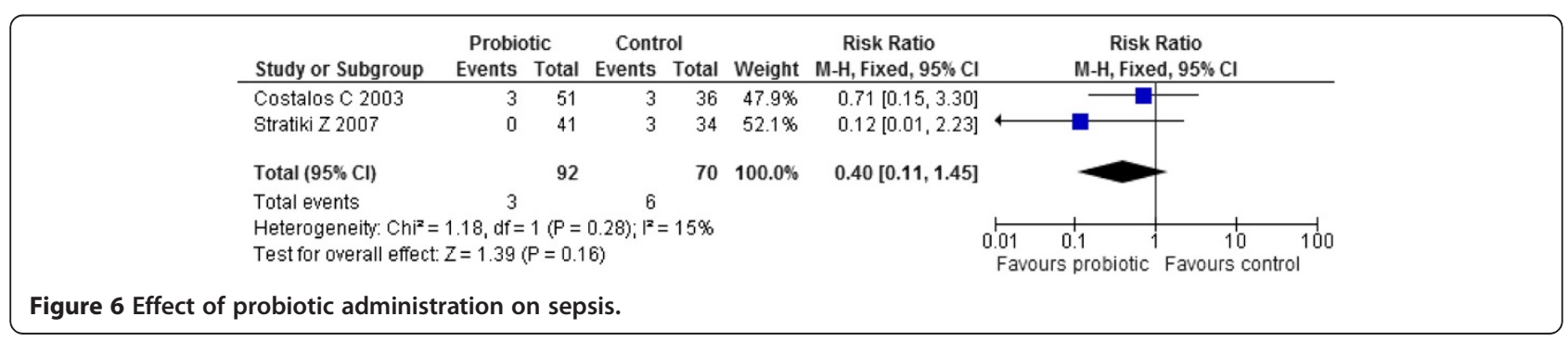


Stool consistency No study reported on the effects of probiotics on stool consistency.

Changes in intestinal permeability Two studies reported this outcome but their results could not be pooled in a meta-analysis $[39,40]$. The studies used two different tests to test for intestinal permeability. Costalos 2003 used a 1-hour D-Xylose blood test and reported no statistically significant difference between the two groups ( $>0.1$ ) [median (IQR) of $1.5(0.4)$ millimols/L for the probiotics $(\mathrm{n}=51)$ and $1.35(0.3) \mathrm{mmol} / \mathrm{L}$ for the control $(n=36)$ ] [39]. Stratiki 2007 used a lactulose/mannitol (L/M) urine test and reported no statistically significant difference in the $\mathrm{L} / \mathrm{M}$ ratios between the probiotic and control groups $(\mathrm{p}=0.073)$ but the values for median (range) were presented in a figure from which they could not be accurately extracted [40].

\section{Changes in gastrointestinal micro flora}

Bifidobacteria Two studies reported on bifidobacteria but their results could not be pooled in a meta-analysis [39,40]. Costalos 2003 reported a significantly higher log viable Bifidobacteria counts per gram of positive infants in the probiotics group compared to the controls $(\mathrm{p}<0.001)$ [median (IQR) of $2.65(0.083)$ for the probiotics group $(\mathrm{n}=51)$ and $2.27(0.075)$ for the control group $(\mathrm{n}=36)]$ [39]. Stratiki 2007 reported bifidobacteria in terms of $\log 10$ $\mathrm{cfu} / \mathrm{g}$ wet feces but found no statistically significant difference between the two groups $(\mathrm{p}=0.075)$ [median (range) of $9.7(7.5-10.3)$ for the probiotics group $(n=41)$ and 8.9 (7.2-10.2) for the control group $(n=34)]$ [40].

Lactobacillus Only one study reported on lactobacillus [39]. This study reported no statistically significant difference in the $\log$ viable bacterial lactobacillus counts per gram of positive infants between the two groups ( $>0.05)$ [median (IQR) of 1.57 (0.285) for the probiotics group $(\mathrm{n}=51)$ and $1.42(0.287)$ for the control group $(n=36)]$.

Pathogens Only one study reported this outcome (enterococci, bacteroides, and staphylococci) in terms of the median (IQR) of log viable bacterial counts per gram of positive infants [39] (Table 6). The study reported significantly higher counts of Enterococci $(\mathrm{p}<0.05)$ and Staphylococci $(\mathrm{p}<0.001)$ in the probiotic group compared to the controls. However, the study found no statistically significant difference in the counts of bacteroides between the two groups ( $p>0.05)$.

\section{Prebiotic versus control}

Four studies investigated the effect of prebiotics administration versus no prebiotics (control group) [36,43-45].
Table 6 Log viable bacteria counts per gram of stool in positive infants fed probiotics

\begin{tabular}{|c|c|c|}
\hline \multirow{2}{*}{$\frac{\text { Costalos } 2003 \text { [39] }}{\text { Pathogens }}$} & \multicolumn{2}{|c|}{ Median (IQR) } \\
\hline & Probiotic & Control \\
\hline & $n=51$ & $n=36$ \\
\hline Enterococci & $2.14(0.359)$ & $2.19(0.138)$ \\
\hline Bacteriodes & $2.17(0.164)$ & $2.25(0.363)$ \\
\hline Staphylococci & $1.23(0.869)$ & $0.6(0.281)$ \\
\hline
\end{tabular}

\section{Primary outcomes: short-term growth parameters}

Weight gain All four studies reported on weight gain $[36,43-45]$. Results from three studies $(n=106)$ were pooled in a meta-analysis $[36,43,45]$. Moderate heterogeneity was observed between the studies $\left(\mathrm{Chi}^{2}=4.04\right.$, $\left.\mathrm{p}=0.13, \mathrm{I}^{2}=51 \%\right)$. An investigation of heterogeneity by subgroup analysis with respect to the prebiotic type used (GOS/ FOS versus FOS only) yielded statistically significant subgroup differences $\left(\mathrm{Chi}^{2}=4.04, \mathrm{df}=1, \mathrm{p}=0.04\right.$, $\left.\mathrm{I}^{2}=75.2 \%\right)$ implying that prebiotic type may be the source of heterogeneity. There was no statistically significant heterogeneity between the two studies in the GOS/ FOS subgroup $\left(\mathrm{Chi}^{2}=0.01, \mathrm{df}=1, \mathrm{p}=0.94, \mathrm{I}^{2}=0 \%\right)[36,43]$. The results for the GOS/FOS subgroup yielded no significant difference in weight gain ( $\mathrm{g} /$ day) between the two groups (MD 0.04, 95\% CI: -2.65 to $2.73, \mathrm{n}=50,2$ studies) while the other FOS subgroup yielded a significantly higher weight gain in controls compared to the prebiotics (MD $-4.60,95 \%$ CI: -8.24 to $-0.96, n=56,1$ study). (Figure 7) Sensitivity analysis with respect to study quality could not be done because all three studies were of poor quality since the methods used for sequence generation, allocation concealment and blinding were all not clear.

Mihatsch 2006 reported no statistically significant difference in weight gain $(\mathrm{g} / \mathrm{kg} /$ day $)$ between the two groups ( $\mathrm{p}=0.4$ ) [median (range) of 17.6 (8.1 to 23.4) for the prebiotic group $(\mathrm{n}=10)$ compared to 13 (9.3 to 21.9) for the control group $(n=10)]$ [44].

Linear growth Three studies reported on length gain $[36,43,45]$. Meta-analysis of the results from these three studies $(n=106)$ revealed significant heterogeneity between the three studies $\left(\mathrm{Chi}^{2}=139.41, \mathrm{df}=2, \mathrm{p}<\right.$ $\left.0.00001, I^{2}=99 \%\right)$. An investigation of heterogeneity by subgroup analysis with respect to the prebiotic type used (GOS/ FOS versus FOS only) yielded statistically significant subgroup differences $\left(\mathrm{Chi}^{2}=139.41, \mathrm{df}=1\right.$, $\left.\mathrm{p}<0.00001, \mathrm{I}^{2}=0 \%\right)$ implying that prebiotic type may be the source of heterogeneity. There was no statistically significant heterogeneity between the two studies in the GOS/ FOS subgroup $\left(\mathrm{Chi}^{2}=0.17, \mathrm{df}=1, \mathrm{p}=0.68, \mathrm{I}^{2}=0 \%\right)$. $[36,43]$. The results for the GOS/FOS subgroup yielded 


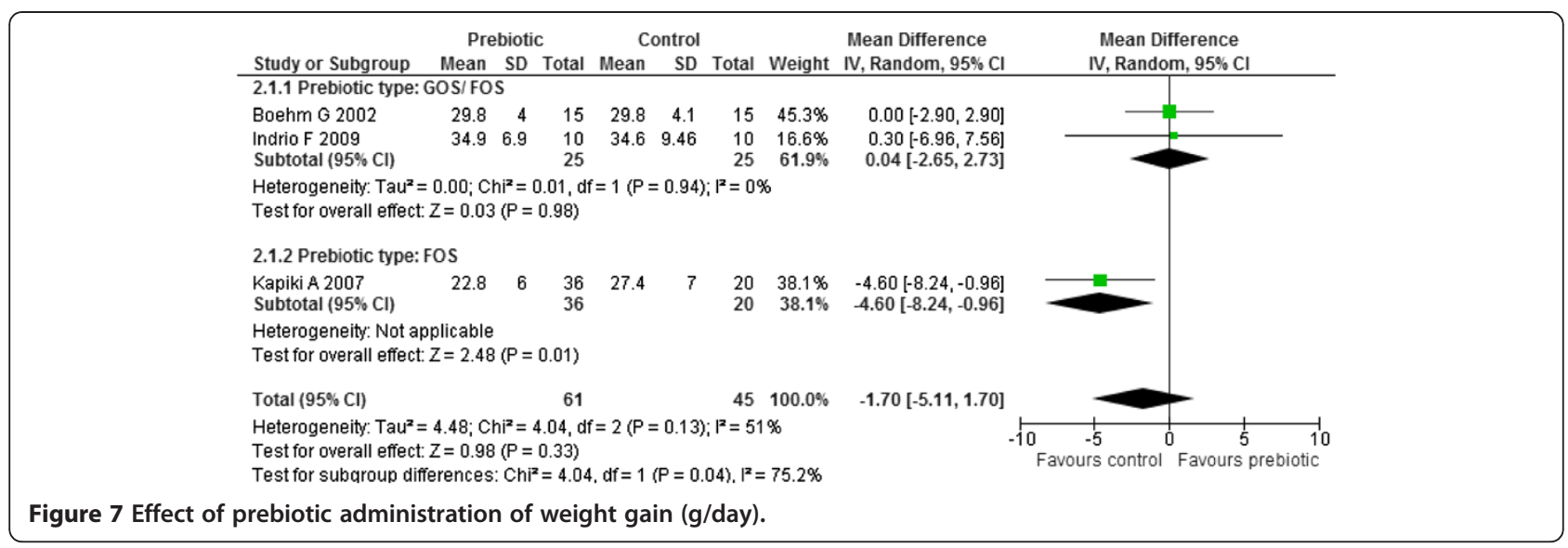

no statistically significant difference in length gain $(\mathrm{cm} /$ week) between the two groups (MD 0.01, 95\% CI: -0.03 to $0.04, n=50,2$ studies) while the other FOS subgroup yielded a significantly higher length gain $(\mathrm{cm} /$ week) in prebiotics compared to the controls (MD 0.30, 95\% CI: 0.27 to $0.33, n=56,1$ study). (Figure 8) Sensitivity analysis with respect to study quality could not be done because all three studies were of poor quality since the methods used for sequence generation, allocation concealment and blinding were all not clear.

Head growth Two studies reported on head growth (cm/week) [43,45]. Meta-analysis of the results from these two studies $(n=76)$ failed to yield statistically significant difference in head growth (MD -0.01, 95\% CI: -0.02 to 0.00$)$. No significant heterogeneity was detected between the two studies $\left(\mathrm{Chi}^{2}=0.10, \mathrm{p}=0.75, \mathrm{I}^{2}=0 \%\right)$.

\section{Secondary outcomes}

Complications No prebiotic study reported on Necrotizing Enterocolitis (NEC), Sepsis, other infections and mortality.

\section{Feeding tolerance}

Number of days on parenteral nutrition No study reported on parenteral nutrition.

Age at full enteral feed Two studies reported on age at full enteral feeds [36,45]. Meta-analysis of the results from these two studies $(n=86)$ did not find statistically significant difference in the age at full enteral feed (MD -0.79 , 95\% CI: -2.20 to 0.61$)$. No significant heterogeneity was detected between the two studies $\left(\mathrm{Chi}^{2}=1.16\right.$, $\left.\mathrm{p}=0.28, \mathrm{I}^{2}=14 \%\right)$.

Maximal enteral feed Two studies reported on this outcome but their results could not be pooled in a meta-analysis [36,44]. Boehm 2002 reported the feeding volume $(\mathrm{ml} / \mathrm{kg} /$ day $)$ in terms of the mean (SD) and therefore a mean difference was calculated. There was no statistically significant difference in feeding volume between the prebiotics group $(n=15)$ and control groups $(\mathrm{n}=15)(\mathrm{MD}-4.10,95 \% \mathrm{CI}:-18.16$ to 9.96$)$ [36].

Mihatsch 2006 reported no statistically significant difference in the average formula intake within the study period $(\mathrm{ml} / \mathrm{kg} / \mathrm{d})$ between the two groups $(\mathrm{p}=0.35)$ [median (range) of 156 (127 to 165) for the prebiotic group

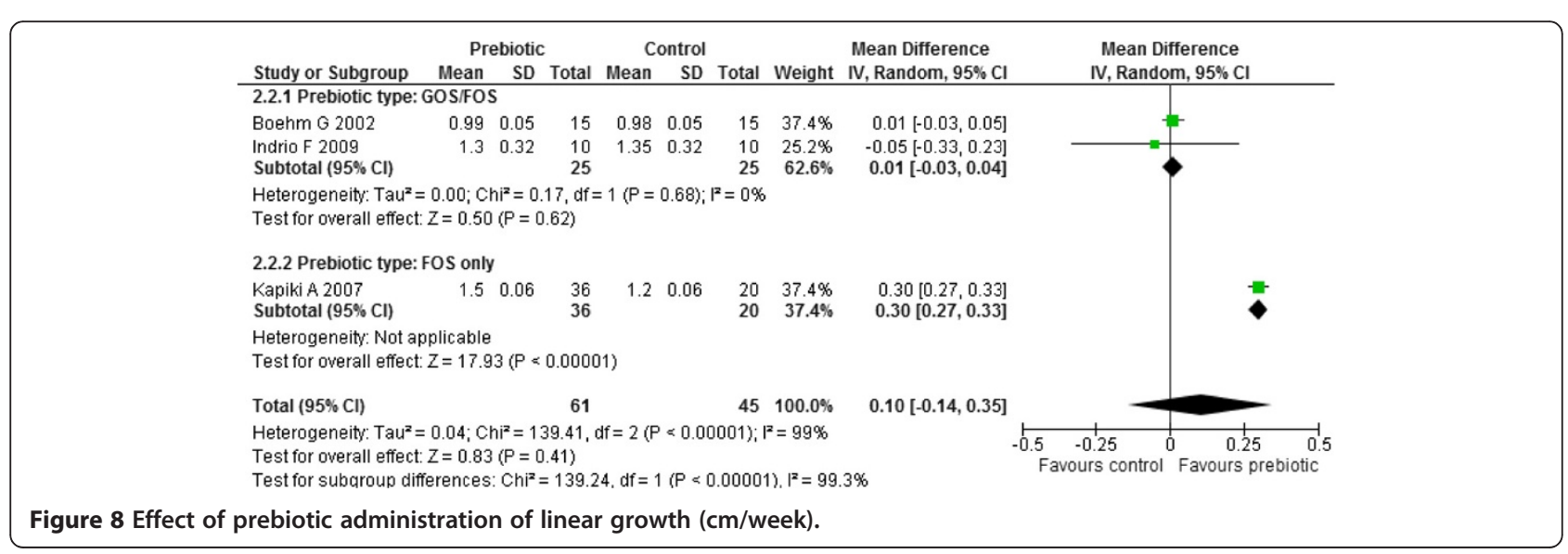


$(n=10)$ compared to 151 (117 to 169) for the control group $(n=10)]$ [44].

Feed tolerance: vomiting, gastric aspirate, abdominal distension, diarrhea All four studies reported this outcome $[36,43-45]$. In all 4 studies $(n=126)$, there were no observed incidences of feed intolerance. There was no vomiting, gastric aspirate removed, no abdominal distension or diarrhea reported. All infants tolerated the preterm formula with prebiotic or control. From further communication with study authors, 2 study authors $[43,44]$ responded that none of these outcomes were observed.

\section{Stool characteristics}

Stool frequency Three studies reported on stool frequency $[36,44,45]$. Two studies reported the results in form of mean (SD) of the number of stools per day (number/ day) [36,45]. Meta-analysis of results from these two studies $(n=86)$ showed a significantly higher stool frequency in the prebiotic group compared to the control group (MD 0.80, 95\% CI: 0.48 to 1.1). No significant heterogeneity was detected between the two studies $\left(\mathrm{Chi}^{2}=0.13, \mathrm{p}=0.72, \mathrm{I}^{2}=0 \%\right)$ (Figure 9).

Mihatsch 2006 reported no statistically significant difference in stool frequency between the two groups $(\mathrm{p}=0.059)$ [median (range) of 3.6(1.7 to 6.9) stools/day in prebiotic group $(\mathrm{n}=10)$ compared to 2.6 (2 to 4.9$)$ stools/ day in control group $(n=10)]$ [44].

Stool consistency Three studies reported on stool consistency but using three different scales of measurement $[36,44,45]$. Although two studies [36,45] both measured consistency in form of a scale ranging from 1 to 5 and reported their results as mean (SD), they could not be pooled in a meta-analysis because their scales were going in opposite directions; Boehm 2002 (1=watery, 2=soft, 3 =seedy, 4=formed, 5=hard) [36]. Kapiki 2007 (5=watery, 4=loose, 3 =soft, 2 =firm, hard=1) [45]. The mean differences for these two studies were therefore calculated separately.

In Boehm 2002, the stools from the prebiotic group $(n=15)$ were significantly more watery as compared to the control group $(\mathrm{n}=15)$. (MD $-0.91,95 \% \mathrm{CI}:-1.41$ to -0.37$)$ [36]. In Kapiki 2007, the stools from the prebiotic group $(\mathrm{n}=36)$ were significantly harder as compared to the control group ( $\mathrm{n}=20)$. (MD -0.34, 95\% CI: -0.66 to -0.02 ) [45].

Mihatsch 2006 reported a statistically significantly lower stool viscosity at day 14 (Newtons) for the prebiotics compared to controls $(\mathrm{p}=0.006)$ [median (range) of 31.8 (1.9 to 67.3$)$ in the prebiotic group $(n=10)$ compared to 157.5 (24.1 to 314.0$)$ in the control group $(\mathrm{n}=10)][44]$.

\section{Changes in intestinal permeability}

No prebiotic study reported on changes in intestinal permeability.

\section{Changes in gastrointestinal micro flora}

Bifidobacteria Two studies reported on this outcome $[36,45]$. Meta-analysis of these two studies $(n=84)$ revealed statistically significant heterogeneity between the two studies $\left(\mathrm{Chi}^{2}=7.63, \mathrm{p}=0.006, \mathrm{I}^{2}=87 \%\right)$. An investigation of heterogeneity by subgroup analysis with respect to the prebiotic type used (GOS/ FOS versus FOS only) yielded statistically significant subgroup differences $\left(\mathrm{Chi}^{2}=7.63, \mathrm{p}=0.006, \mathrm{I}^{2}=86.7 \%\right)$ implying that prebiotic type may be the source of heterogeneity. The results for the GOS/FOS subgroup yielded significantly higher bifidobacteria counts in prebiotics compared to controls (MD 2.10, 95\% CI: 0.96 to 3.24) [36]. The other FOS subgroup also yielded significantly higher bifidobacteria counts in prebiotics compared to controls (MD 0.48, 95\% CI: 0.28 to 0.68) [45] (Figure 10).

Lactobacilli Only one study [36] reported this outcome but the actual values were not given.

Pathogens [Post-intervention] Two studies reported on this but their results could not be pooled in a metaanalysis [36,45]. Boehm 2002 reported the sum of clinically relevant pathogens at the end of the intervention period in the form of mean (SD) log $\mathrm{cfu} / \mathrm{g}$ stool. The values were used to calculate the mean difference which showed that the sum of the studied pathogens was significantly lower in the prebiotic group $(n=12)$ compared to the control group $(\mathrm{n}=13)$. (MD $-0.43,95 \% \mathrm{CI}:-0.79$ to -0.07$)$ [36].

\begin{tabular}{|c|c|c|c|c|c|c|c|c|c|c|}
\hline & Study or Subgroup & \multicolumn{3}{|c|}{ Prebiotic } & \multicolumn{3}{|c|}{ Control } & \multicolumn{2}{|r|}{ Mean Difference } & $\begin{array}{l}\text { Mean Difference } \\
\text { IV, Fixed, } 95 \% \mathrm{Cl}\end{array}$ \\
\hline & Boehm G 2002 & 2.2 & 0.8 & 15 & 1.33 & 0.6 & 15 & $39.2 \%$ & $0.87[0.36,1.38]$ & 를 \\
\hline & Kapiki A 2007 & 3.05 & 0.95 & 36 & 2.3 & 0.6 & 20 & $60.8 \%$ & $0.75[0.34,1.16]$ & $\square$ \\
\hline & Total $(95 \% \mathrm{Cl})$ & & & 51 & & & 35 & $100.0 \%$ & $0.80[0.48,1.11]$ & $\downarrow$ \\
\hline & $\begin{array}{l}\text { Heterogeneity: } \mathrm{Chi}^{2}= \\
\text { Test for overall effect: }\end{array}$ & $\begin{array}{l}0.13, \mathrm{df}= \\
Z=4.93\end{array}$ & $\begin{array}{l}=1(P= \\
(P<0\end{array}$ & $\begin{array}{l}=0.72) i \\
0.00001\end{array}$ & ;) $1^{2}=0 \%$ & & & & & 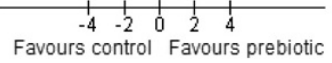 \\
\hline
\end{tabular}


Kapiki 2007 reported this outcome (staphylococci, E. coli, bacteroides, and enterococci) in terms of mean (SD) $\log 10 \mathrm{CFU} / \mathrm{g}$ wet feces [45]. Mean differences for each of these pathogens were calculated. There was no statistically significant difference in the number of staphylococci (MD 0.00, 95\% CI: -0.17 to 0.17 ) between the two groups but there were significantly fewer E. coli (MD $-1.69,95 \% \mathrm{CI}:-1.85$ to -1.53 ) and enterococci (MD $-0.80,95 \% \mathrm{CI}:-0.99$ to -0.61 ) in the prebiotic group $(n=36)$ compared to the control group $(n=20)$. With regards to bacteroides, there were significantly more bacteroides in the prebiotic group $(n=36)$ compared to the control group $(n=20)$ (MD 0.50, 95\% CI: 0.36 to 0.64 ) [45].

\section{Discussion}

The objective of this review was to assess if addition of probiotics or prebiotics to preterm infant formula led to improved growth and clinical outcomes in preterm or low birth weight infants. Studies that used breast milk or mixed feeds (breast milk and infant formula) were excluded. All RCTs evaluated probiotics or prebiotic use in preterm infants, were of small sample size, varied in enrolment criteria, intervention, treatment initiation and duration.

\section{Summary of main findings \\ Probiotics}

This review was under powered to detect clinically important differences in primary outcomes (weight gain, linear growth, head growth) because of the few number of studies, small sample size $(n=34)$ and poor methodological quality of studies. This review found no significant effect on weight gain from use of probiotics added to infant formula. There was also no significant probiotic effect on linear and head growth from the one study measuring these two outcomes. Probiotic supplementation failed to significantly reduce the risk of complications such as NEC, sepsis and death compared to control group. Outcomes such as number of days on parenteral nutrition and other infections were not reported. There was no significant difference in the amount of feed volume ( $\mathrm{ml} /$ day) and frequency of vomiting between study groups. Preterm infant formula with probiotics was well tolerated as no gastric aspirates, abdominal distension or diarrhea was reported. Effects of probiotics on stool characteristics were under reported. Results from one study showed probiotics supplementation did result in a larger number of stools per day.

Effects on intestinal permeability could not be evaluated since two different laboratory tests (lactulose / mannitol ratio and D- xylose tests) were reported and the results could not be pooled. Sugar absorption tests (such as lactulose / mannitol ratio) are a direct measure of intestine integrity which reflects gut maturation and in research; they demonstrate the effects of experimental therapy $[78,79]$. Monitoring changes in intestinal permeability in preterm infants is essential since there is evidence that initiation of enteral feeds decreases intestinal permeability $[78,80]$. However, this could not be established in this review. Other outcomes such as age at full enteral feeds and intestinal micro flora (pathogens) could not be evaluated as medians (inter quartile ranges) were reported. No probiotic study reported any data on low birth weight infants therefore no conclusions could be made on this population.

The included probiotic studies had short treatment duration of 30 days. This confirms the European Society for Pediatric, Gastroenterology, Hepatology and Nutrition (ESPGHAN) statement that there is a "lack of published evidence on clinical benefits from long term use of probiotic containing infant formula" [81]. This review confirms that there is a need for long term follow-up RCTs on preterm infants. Live probiotic bacteria were used in the trials. There have been few reports of bacteraemia from probiotic use in the biomedical literature [82-84]. There were no cases of sepsis reported as a result of probiotic consumption in the included studies. In recent reviews, the time to reach full enteral feeds was 
earlier in the preterm infants given probiotics with breast milk or mixed feeds. This review could not evaluate this outcome. Well-designed RCTs with similar feeding regimes are needed to evaluate this outcome.

\section{Prebiotics}

This review was under powered to detect clinically important differences in primary outcomes (weight gain, linear growth, head growth) because of few number of studies, small sample size $(\mathrm{n}=106)$ and poor methodological quality of studies. Addition of prebiotic combinations of GOS /FOS or FOS alone to preterm infant formula did not have any significant effect on weight gain. Addition of GOS / FOS to preterm infant formula did not have any effect on linear growth. However, addition of FOS alone did have a significant effect on linear growth. Neither GOS / FOS combination nor FOS alone had any effect on head growth.

None of the prebiotic studies reported on NEC, sepsis, other infections, mortality (death), parenteral nutrition or changes in intestinal permeability; therefore these outcomes could not be evaluated. Prebiotics did not have any significant effect on the age at which infants reached full enteral feeds or volume of feed tolerated. Prebiotic preterm formula was well tolerated because there were no reports of vomiting, gastric aspirates, abdominal distension or diarrhea. Prebiotic supplementation did result in a higher stooling frequency compared to control. Effects on stool consistency were inconclusive as results from one study resulted in more watery stools in the prebiotic study group compared to control group, in a second study, the prebiotic group experienced harder stools compared to control group. The third study results were presented in medians (range) therefore no conclusions could be made. In preterm infants, frequent watery stools may signify intolerance, a transient lactase deficiency or another pathological state which always require further investigation [6].

Prebiotics did have a significant effect on intestinal micro flora. Addition of GOS / FOS combination or FOS alone significantly increased counts of bifidobacteria. Effects on lactobacillus counts could not be evaluated as actual figures were not available. The sum of studied pathogens and some selected pathogens (E- coli, enterococci) were significantly fewer in the prebiotic group compared to control group. There was no effect on staphylococci levels while bacteroides were significantly higher in the probiotic group compared to control group. No prebiotic study reported any data on low birth weight infants; therefore no evaluations could be made.

The prebiotic studies were of short duration ranging from 14 to 28 days. The dose of the prebiotic used (GOS, FOS) varied from $0.4 \mathrm{~g} / \mathrm{dl}$ o $1 \mathrm{~g} / \mathrm{dl}$. The European Committee on Food recommends that prebiotics added to formula milk do not exceed $0.8 \mathrm{~g} / 100 \mathrm{ml}$. The rationale for prebiotic doses not exceeding $1 \mathrm{~g} / \mathrm{ml}$ in clinical trials is an attempt to maximize the bifidogenic effect with minimal intolerance as exhibited by, abdominal distension [85]. The preterm infants tolerated the prebiotic formula as there were no symptoms of feed intolerance reported.

Prebiotic supplementation did have some short term benefits: increased stooling frequency and bifidobacteria counts, fewer pathogens in the prebiotic group compared to control group. However, large RCTS with long term follow -up are needed to find out if these short term benefits translate into improved general health and reduced morbidities in preterm infants. Due to the short duration of prebiotic studies, routine supplementation with prebiotics in preterm infants cannot be recommended.

\section{Quality of the evidence and potential biases}

In this review, the quality of the evidence was compromised by several factors: Sample size: included studies were of small individual sample size, number of study participants ranged from 20 to 87 in the probiotic studies, 20 to 56 in prebiotic studies. Intervention: Different types of probiotic and prebiotics, doses and treatment duration were used. Methodological quality: Inadequate information was published to assess methodological quality of the studies. Information was missing on sequence generation, allocation concealment, blinding, incomplete outcome data, selective reporting and free of other bias domains. The significance of any relationship between methodological quality and study outcomes could not be verified since no subgroup analysis with respect to study quality could be done as a result of either too few studies in a meta-analysis or having all studies with similar quality in a meta-analysis. Not all the reviews pre- specified outcomes were addressed by the included studies.

At the conclusion of the review process and preparation of the manuscript (for this review), one on- going study was terminated due to being under powered [47]. One study was completed and data analysis commenced. The results from this study could not be included in this review [48]. The other three studies were still on-going $[46,49,50]$. The reviewers used thorough comprehensive search strategies adopted for the available databases. All attempts were made to minimize publication bias. All steps of this review were conducted independently by the reviewers.

\section{Agreements and disagreements with other reviews}

No significant difference was found in contrast with past reviews and that the potential reasons are lack of power, poor quality of studies or a lack of effect in formula fed 
infants. This review did agree with some aspects of past reviews. Prebiotics did have an impact on GI micro flora (increased bifidobacteria counts, reduction in certain pathogens); feed tolerance (no reported gastric aspirates, abdominal distension).

\section{Conclusion}

There is not enough evidence to state that supplementation of preterm infant formula with probiotics or prebiotics does result in improved growth and clinical outcomes in preterm infants. Therefore this review does not support the routine supplementation of preterm formula with probiotics or prebiotics.

\section{Implications for research}

For clear recommendations to be made, long term large RCTs on exclusively formula fed preterm and low birth weight infants are required to investigate the effects of probiotics and prebiotics supplementation in preventing NEC, sepsis, death/mortality; changes in intestinal micro flora and intestinal permeability; explore the efficacy of different doses of the same probiotic on clinical outcomes because available studies used different probiotic doses; similarly, explore the efficacy of different doses of the same prebiotic on clinical outcomes because available studies used similar prebiotics with different doses and treatment duration.

\section{Abbreviations \\ Cfu: Colony forming units; Cl: Confidence interval; $\mathrm{cm}$ : Centimetres; ESPGHAN: European society for pediatric gastroenterology, hepatology and nutrition; FOS: Fructo-oligosaccharide; GI: Gastrointestinal; GOS: \\ Galacto-oligosaccharide; IQR: Inter quartile range; IFN- $\gamma$ : Interferon - gamma; IL-6: Interleukin - 6; IL-10: Interleukin - 10; IL-1ß: Interleukin - 1beta; kg: Kilogram; L/M: Lactulose mannitol; MD: Mean difference mmol: millimols; ml: Millilitres; NEC: Necrotizing enterocolitis; TNF-a: Tissue necrosis factor - alpha; RCTs: Randomized controlled trials; RR: Risk ratio; SD: Standard deviation; USA: United States of America; WHO: World Health Organisation.}

\section{Competing interests}

The authors declared that they have no competing interests.

\section{Authors' contributions}

The authors contributed the following: MM: Developed review protocol, selected RCTs, carried out data extraction; assessment of risk of bias in included studies, developed, edited and critically reviewed the manuscript. ML: Selected RCTs, carried out data extraction, assessment of risk of bias in included studies, critically reviewed the manuscript. AM: Carried out the statistical analysis, interpretation of results and critically reviewed the manuscript. TY: Assisted in designing the review and critically reviewed the manuscript. RB: Assisted in designing the review and critically reviewed the manuscript. All authors read and approved the final manuscript.

\section{Acknowledgments}

This review was supported through a grant from the University of Stellenbosch, Faculty of Health Sciences, South Africa. The funders played no role in study design, data collection, analysis and interpretation, report writing or conclusions reached in this review.

\section{Author details}

${ }^{1}$ Division of Human Nutrition, Faculty of Medicine and Health Sciences, Stellenbosch University, P.O Box 19063, Tygerberg 7505, South Africa. ${ }^{2}$ Wits Reproductive Health \& HIV Institute (WRHI), Faculty of Health Sciences,
University of the Witwatersrand, Johannesburg, South Africa. ${ }^{3}$ Centre for Evidence-Based Health Care, Faculty of Medicine and Health Sciences, Stellenbosch University, Tygerberg, South Africa.

Received: 25 October 2011 Accepted: 26 July 2012

Published: 28 August 2012

\section{References}

1. Anderson DM: From Pediatric Nutrition. In Handbook of Pediatric Nutrition. 3rd edition. Edited by Samour PQ, Helm KK. Sudbury, Massachusetts: James and Bartlett Publishers; 2005:53-71.

2. Lissauer T, Clayden G: Neonatal Medicine. In Illustrated Text book of Pediatrics. 3rd edition. Mosby: Elsevier; 2007:145-168.

3. Georgieff MK: Nutrition. In Avery's Neonatology pathophysiology and management of the new born. 6th edition. Edited by MacDonald MG, Seshia MMK, Mullet MD. Philadelphia: Lippincott Williams and Wilkins; 2005:380-381.

4. Lissauer T, Fanaroff A: The preterm infant: growth and nutrition. In Neonatology at a glance. Malden, Mass: Blackwell Publishing; 2006:76-77.

5. Uhing MR, Das UG: Optimizing growth in the preterm infant. Clin Perinatol 2009, 36:165-176.

6. Anderson MS, Johnson CB, Townsend SF, Hay W Jr: Enteral nutrition. In Handbook of neonatal intensive care. 5 th edition. Edited by Merenstein GB, Gardner SL. Mosby: Mosby; 2002:314-316.

7. Corpeleijin WE, van Vliet I, de Gast-Bakker DH, van der Schoor SRD, Alles MS, Hoijer M, Tibboel D, van Goudoever JB: Effect of enteral IGF-1 supplementation on feeding tolerance, growth and gut permeability in enterally fed premature neonates. J Pediatr Gastrotenterol Nutr 2008, 46:184-190.

8. Chauhan M, Henderson GM, McGuire W: Enteral feeding for very low birth weight infants: reducing the risk of necrotising enterocolitis. Arch Dis Child Fetal Neonatal Ed 2008, 93:F162-F166.

9. Underwood MA, Salzmand $\mathrm{NH}$, Bennett $\mathrm{SH}$, Barman M, Mills DA, Marcobal A, Tancredi DJ, Bevins CL, Sherman M: A randomized placebo - controlled comparison of 2 prebiotic/probiotic combinations in preterm infants: Impact on weight gain, intestinal microbiota and fecal short chain fatty acids. J Pediatr Gastroenterol Nutr 2009, 48:216-225

10. Shah NP: Functional cultures and health benefits. Int Dairy J 2007 17:1262-1277.

11. Parvez S, Malik KA, Kang SA, Kim HY: Probiotics and their fermented food products are beneficial for health. J Appl Microbio/ 2006, 100:1171-1185.

12. Gibson GR, Nathalie D: Inulin and oligofructose. New Scientific Developments. Nutr Today 2008, 43:54-59.

13. Gibson GR: Fibre and effects on probiotics (the prebiotic concept). Clin Nutr 2004, 1(2):25-31.

14. Macfarlane GT, Steed $H$, Macfarlane S: Bacterial metabolism and health related effects of galacto-oligosaccharides and other prebiotics. J Appl Microbiol 2008, 104:305-344.

15. Losada M, Olleros T: Towards a healthier diet for the colon: the influence of fructooligosaccharides and lactobacilli on intestinal health. Nutr Res 2002, 22:71-84.

16. Watzl B, Girrbach S, Monika R: Inulin, Oligofructose and immunomodulation. Br J Nutr 2005, 93(Suppl 1):S49-S55

17. FAO/WHO: Guidelines for evaluation of probiotics in food. 2002. http/www. who.int/foodsafety/fs_management/en/probiotic_guidelines.pdf.

18. Gill HS: Probiotics enhance anti- effective defences in the gastrointestinal tract. Best Pract Res Clin Gastroenterology 2003, 17:755-773.

19. Schlee M, Harder J, Koten B, Stange EF, Wehkamp J, Fellermann K: Probiotic lactobacilli and VSL\#3 induce enterocyte beta-defensin 2. Clin Exp Immunol 2008, 151:528-535.

20. Fedorak RN, Madsen KK: Probiotics and prebiotics in gastrointestinal disorders. Curr Opin Gastroenterol 2004, 20:146-155.

21. Resta-Lenert S, Barrett KE: Live probiotics protect intestinal epithelial cells from the effects of infection with entero invasive Escherichia Coli (EIEC). Gut 2003, 52:988-997.

22. Heyman M, Terpend K, Menard S: Effects of specific lactic acid bacteria on the intestinal permeability to macromolecules and the inflammatory condition. Acta Pediatr 2005, 94(Suppl 449):34-36.

23. Boirvant $M$, Strober $W$ : The mechanism of action of probiotics. Curr Opin Gastroenterol 2007, 23:670-692. 
24. Olivares M, Diaz-Ropero MP, Gómez N, Lara-Villoslada F, Sierra S, Maldonado JA, Martin R, Lopez-Huetas E, Rodriguez JM, Xaus J: Oral administration of two probiotic strains Lactobacillus gasseri CECT5714 and Lactobacillus coryniformis CECT5711, enhances the intestinal function of healthy adults. Int J Food Microbiol 2006, 107:104-111.

25. Wult M, Hagslatt ML, Odenholt I, Berggren A: Lactobacillus planatarum $299 \mathrm{v}$ enhances the concentrations of fecal short chain fatty acids in patients with recurrent clostridium difficile associated diarrhea. Dig Dis Sci 2007, 52:2082-2086.

26. Calame W, Weseler AR, Viebke C, Flynn C, Siemensma AD: Gum Arabic establishes prebiotics functionality in healthy human volunteers in a dose dependent manner. Br J Nutr 2008, 100:1269-1275.

27. Cherbut C, Michel C, Raison V, Kravtchenko T, Severine M: Acacia gum is a bifidogenic dietary fibre with high digestive tolerance in healthy humans. Microb Ecol Health Dis 2003, 15:43-50.

28. Guarner F: Studies with Inulin type fructans on intestinal infections, permeability and inflammation. J Nutr 2007, 137:2568S-2571S.

29. Vlieger AM, Robroch A, van Buuren S, Kiers J, Rijkers G, Benninga MA Tebiesebeke R: Tolerance and safety of lactobacillus paracasei ssp paracasei in combination with Bifidobacterium animalis ssp lactis in a prebiotic-containing infant formula: a randomised controlled trial. $\mathrm{Br} J$ Nutr 2009, 102:869-875.

30. Kullen MJ, Bettler J: The delivery of probiotics and prebiotic to infants. Curr Pharm Des 2005, 11:55-74.

31. AlFaleh K, Anabrees J, Bassler D, Al-Kharfi T: Probiotics for prevention of necrotizing enterocolitis in preterm infants. Cochrane Database Sys Rev 2011, Art. No. CD005496(Issue 3). doi:10.1002/14651858.CD005496.pub3.

32. Barclay AR, Stenson B, Simpson JH, Lawrence T, Wilson D: Probiotics for Necrotizing Enterocolitis: A Systematic Review. J Pediatr Gastroenterol Nutr 2007, 45:569-576.

33. Deshpande G, Rao S, Patole S: Probiotics for prevention of necrotising enterocolitis in preterm neonates with very low birth weight: a systematic review of randomised controlled trials. Lancet 2007, 369(9573):1614-1620.

34. Johnston BC, Goldenberg JZ, Vandvik PO, Sun X, Guyatt GH: Probiotics for the prevention of pediatric antibiotic-associated diarrhea. Cochrane Database Sys Rev 2011, Art. No. CD004827(Issue 11). doi:10.1002/14651858. CD004827.pub3.

35. Higgins JPT, Green S: Cochrane Handbook for Systematic Reviews of Interventions. Chichester (UK): John Wiley \& Sons; 2008.

36. Boehm G: Supplementation of a bovine milk formula with an oligosaccharide mixture increases counts of faecal bifidobacteria in preterm infants. Arch Dis Child Fetal Neonatal Ed 2002, 86:F178-F181.

37. Knol J, Boehm G, Lidestri M, Negretti F, Jelinek J, Agosti M, Stahl B, Mosca F: Increase of faecal bifidobacteria due to dietary oligosaccharides induces a reduction of clinically relevant pathogen germs in the feces of formula-fed preterm infants. Act Paediatr 2005, Suppl 449:31-33.

38. Boehm G, Fanaro S, Jelinek J, Stahl B, Marini A: Prebiotic concept for infant nutrition. Acta Paediatr 2003, 92(Suppl 441):64-67.

39. Costalos C: Enteral feeding of premature infants with Saccharomyces Boulardii. Early Hum Dev 2003, 74:89-96.

40. Stratiki Z, Costalos C, Sevastiadou S, Kastanidou O, Skouroliakou M Giakoumatou A, Petrohilou V: The effect of a bifidobacter supplemented bovine milk on intestinal permeability of preterm infants. Early Hum Dev 2007, 83:575-579.

41. Reuman PD, Duckworth DH, Smith KL, Kagan R, Bucciarelli R, Ayoub E: Lack of effect of Lactobacillus on gastrointestinal bacterial colonization in premature infants. Pediatr Infect Dis 1986, 5:663-668.

42. Indrio F, Riezzo G, Raimondi F, Biscegua M, Cavallo L, Francailla R: The effects of probiotics on feeding tolerance, bowel habits and gastrointestinal motility in preterm new-borns. J Pediatr 2008, 152:801-806.

43. Indrio F, Riezzo Raimondi F, Francavilla R, Montagna O, Valenzano M, Cavallo L, Boehm G: Prebiotics improve gastric motility and gastric electrical activity in preterm new-borns. J Pediatr Gastroenterol Nutr 2009, 49:258-261.

44. Mihatsch WA, Hoegel J, Pohlandt F: Prebiotic oligosaccharides reduce stool viscosity and accelerate gastrointestinal transport in preterm infants. Acta Paediatr 2006, 95:843-848.

45. Kapiki A, Costalos C, Oikonomidou C, Triantafyllidou A, Loukatou E, Pertrohilou: The effect of a fructooligosaccharide supplemented formula on gut flora of preterm infants. Early Hum Dev 2007, 83:335-339.
46. Jacobs S: The use of probiotics to reduce the incidence of sepsis in premature infants. Australian New Zealand Clinical Trials Registry; ACTRN126070001444415 26/02/2007 [www. anzctr.org.au].

47. Lozano JM, Rojas M: Prophylactic Probiotics in Premature infants. Clinical trials registry; NCT007273632008 [www. clinicaltrials.gov].

48. Al-Hosni M, Duenas M, Ferrelli K, Howard D, Soll R: Probioticssupplemented feeding in extremely low birth weight infants. In Pediatric Academic Society Conference Proceedings at Vancouver Convention Centre. 2010. Abstract Number 1670.8: Course number 1670. (www.pas-meetings. org; www.abstract2view.com)

49. Patole S: A randomized placebo controlled trial on the safety and efficacy of a probiotic product in reducing all case mortality and definite Necrotising Enterocolitis in preterm very low birth weight neonates. Australian New Zealand Clinical Trials Registry; ACTRN12609000374268 27/05/2009 (www. anzctr.org.au).

50. Underwood M: The impact of oligosaccharides and bifidobacteria on the intestinal micro flora of premature infants. Clinical trials registry; NCT00810160 05/11/2009. [www.clinicaltrials.gov].

51. Karvonen AV, Sinkiewicz G, Connoly E, Vesikari T: Safety and colonization of the probiotic Lactobacillus reuteri ATCC 55730 in new born and premature infants. Stockholm, Sweden: Bio Gaia AB Research Laboratories; 2002 (Unpublished data).

52. Agarwal R, Sharma N, Chaudhry R, Deorari A, Paul V, Gewolb $\mid H$, Panigrahi P. Effects of oral Lactobacillus GG in enteric micro flora in low birth weight neonates. J Pediatr Gastroenterol Nutr 2003, 36:397-402.

53. Lin HC, Hsu CH, Chen HL, Chung MY, Hsu JF, Lien Rl, Tsao LY, Chen CH, Su $\mathrm{BH}$ : Oral Probiotics prevent necrotizing enterocolitis in very low birth weight preterm infants: A multicenter, randomized controlled trial. Pediatrics 2008, 122:693-700.

54. Riskin A, Hochwald O, Bader D, Srugo I, Naftali G, Kugelman A, Cohen E, Mor F, Kaufman B, Shaoul R: The effects of Lactulose supplemented enteral feedings in premature infants: A pilot study. J Pediatr 2010, 156:209-214.

55. Andrews BF: Low birth weight infants fed a new carbohydrate- free formula with different sugars. Am J Clin Nutr 1969, 22:845-850.

56. Chou IC, Kuo HT, Chang JS, Wu SF, Chiu HY, Su BH, Lin HC: Lack of effects of oral probiotics on growth and neuro developmental outcomes in preterm very low birth weight infants. J Pediatr 2010, 156:393-396.

57. Stansbridge EM, Walker V, Hall MA, Smith SL, Millar MR, Bacon C, Chen S: Effects of feeding premature infants with Lactobacillus GG on gut fermentation. Arch Dis Child 1993, 69:488-492.

58. Cukrowska B, Lodinova-Zadnikiva R, Enders C, Sonnenborn U, Schulze J, Tlaskalová-Hogenová H: Specific proliferative and antibody responses of premature infants to intestinal colonization with non-pathogenic probiotic E-coli strain nissle 1917. Scan J Immunol 2002, 55:204-209.

59. Bin-Nun A, Bromiker R, Wilschanski M, Kaplan M, Rudensky B, Caplan M, Hammerman C: Oral probiotics prevent necrotising enterocolitis in very low birth weight neonates. J Pediatr 2005, 147:192-196.

60. Manzoni $\mathrm{P}$, Mostert M, Leonessa ML, Priolo C, Farina D, Monetti C, Latino MA, Gomirato G: Oral supplementation with Lactobacillus caseii subspecies rhamnosus prevents enteric colonization by candida species in preterm infant: A randomized study. Clin Infec Dis 2006, 42:1735-1742.

61. Rouge C, Piloquet $H$, Butel MJ, Berger B, Rochat F, Ferraris L, Des RC, Legrand A, de la Cochetière MF, N'Guyen JM, Vodovar M, Voyer M, Darmaun D, Rozé JC: Oral Supplementation with probiotics in very low birth preterm infants: A randomized, double blind, placebo controlled trial. Am J Clin Nutr 2009, 89:1828-1835.

62. Taylor SN, Basile LA, Ebeling M, Wagner C: Intestinal Permeability in Preterm infants by feeding type: Mother's milk versus formula. Breastfeed Med 2009, 4:11-15

63. Hoyos $A B$ : Reduced Incidence of necrotizing enterocolitis associated with enteral administration of lactobacillus acidophilus and bifidobacterium infantis to neonates in an intensive care unit. Int J Infect Dis 1999, 3:197-202.

64. Wang $\mathrm{C}$, Shoji $\mathrm{H}$, Sato $H$, Nagata $S$, Ohtsuka $Y$, Shimizu T, Yamashiro Y: Effects of Oral Administration of bifidobacterium breve on fecal lactic acid and short chain fatty acids in low birth weight infants. J Pediatr Gastroenterol Nutr 2007, 44:252-257.

65. Dani C, Biadaioli R, Bertini G, Martelli E, Rubaltelli F: Probiotics feeding in prevention of urinary tract infection, bacterial sepsis and necrotizing 
enterocolitis in preterm infants. A prospective double blind study. Biol Neonate 2002, 82:103-108.

66. Millar MR, Bacon C, Walker V, Hall MA: Enteral feeding of premature infants with Lactobacillus GG. Arch Dis Child 1993, 69:483-487.

67. Samanta M, Sarkar M, Ghosh P, Ghosh JK, Sinha MK, Chatterjee S: Prophylactic probiotics for prevention of necrotizing enterocolitis in very low birth weight new borns. J Trop Pediatr 2009, 55:128-131.

68. Lidestri M, Agosti M, Marini M: Oligosaccharides might stimulate calcium absorption in formula fed preterm infants. Acta Paediatr 2003, 92(Suppl 441):91-92.

69. Kitajima H, Sumida Y, Tanaka R, Yuki T, Fujimura M: Early Administration of Bifidobacterium breve to preterm infants: Randomised controlled trial. Arch Dis Child 1997, 76:F101-F107.

70. Mohan R, Koebnick C, Schildt J, Schildt S, Mueller M, Possner M, Radke M, Blaut M: Effects of Bifidobacterium lactis Bb12 supplementation on intestinal microbiota of preterm infants: A double blind, placebo controlled randomized study. J Clin Microbio 2006, 44:4025-4031.

71. Westerbeek EAM, van Elburg RM, Van den Berg A, Van den Berg J, Twisk JWR, Fetter WPF, Lafeber HN: Design of a randomised controlled trial on immune effects of acidic and neutral oligosaccharides in the nutrition of preterm infants: Carrot study. BMC Pediatr 2008, 8:46.

72. Lee SJ, Cho SJ, Park EA: Effects of Probiotics on enteric flora and feeding tolerance in preterm infants. Neonatology 2007, 91:174-179.

73. Mohan R, Koebnick C, Schildt J, Mueller M, Radke M, Blaut M: Effects of Bifidobacterium lactis Bb12 supplementation on body weight, fecal $\mathrm{pH}$, acetate, lactate, calprotectin and IgA in Preterm infants. Pediatr Res 2008, 64:418-422.

74. Westerbeek EAM, Van den Berg JP, Lafeber HN, Fetter-Wilem PF, Boehm G, Twisk WR, Van Elburg RM: Neutral and acidic oligosaccharides in preterm infants: a randomized double-blind, placebo controlled trial. Am J Clin Nutr 2010, 91:679-686.

75. Lin HC, Su BH, Chen AC, Lin TW, Tsai CH, Yeh TF, Oh W: Oral probiotics reduce the incidence and severity of necrotizing enterocolitis in very low birth weight infants. Pediatrics 2005, 115:1-4.

76. Patole SK, Muller R: Does Carboxy methylcellulose have a role in reducing time to full enteral feeds? Int J Clin Pract 2005, 59:544-548.

77. Yong G, Fang H, Shuang-Gen M, Guo-Cheng X: Effect of Bifid triple viable on feeding Intolerance in preterm infants with very low birth weight. [Clinical study on the effect of probiotic preparation on feeding intolerance in preterm infants with very low birth weight. (from Chinese translation)]. Chinese Journal of Microecology 2009, 21:451-452.

78. van Elburg RM, Fetter WPF, Bunkers CM, Heymans HSA: Intestinal permeability in relation to birth weight and gestational and postnatal age. Arch Dis Child Fetal Neonatal Ed 2003, 88:F52-F55.

79. Corpeleijn WE, van Elburg RM, van Kema IP, Goudoever JB: Assessment of intestinal permeability in (premature) neonates by sugar absorption tests. Methods Mol Biol 2011, 763:95-104.

80. Westerbeek EAM, van den Berg A, Lafeber HN, Fetter WPF, van Elburg RM: The effect of enteral supplementation of a prebiotic mixture of non-human milk galacto-, fructo- and acidic oligosaccharides on intestinal permeability in preterm infants. Br J Nutr 2011, 105:268-274.

81. Agostoni C, Axelsson I, Braegger C, Goulet O, Koletzko B, Michaelsen KF, Rigo J, Shamir R, Szajewska H, Turck D, Weaver L: Probiotic Bacteria in dietetic products for infants: a commentary by the ESPGHAN Committee on Nutrition. J Pediatr Gastroenterol Nutr 2004, 38:365-374.

82. Guenther K, Straube E, Pfister W, Guenther A, Huebler A: Severe sepsis after probiotic treatment with Escherichia coli nissle 1917. Pediatr Infect Dis J 2010, 29:188-189.

83. Kunz AN, Noel JM, Fairchok MP: Two cases of Lactobacillus bacteremia during probiotic treatment of short gut syndrome. J Pediatr Gastroenterol Nutr 2004, 38:457-458.

84. Land MH, Rouster-Stevens K, Woods CR, Cannon ML, Cnota J, Shetty AK Lactobacillus sepsis associated with probiotic therapy. Pediatrics 2005, 115:178-181.

85. Veereman G: Pediatric applications of inulin and oligofructose. J Nutr 2007, 137:2585S-2589S.

doi:10.1186/1475-2891-11-58

Cite this article as: Mugambi et al:: Probiotics, prebiotics infant formula use in preterm or low birth weight infants: a systematic review. Nutrition Journal 2012 11:58.

\section{Submit your next manuscript to BioMed Central and take full advantage of:}

- Convenient online submission

- Thorough peer review

- No space constraints or color figure charges

- Immediate publication on acceptance

- Inclusion in PubMed, CAS, Scopus and Google Scholar

- Research which is freely available for redistribution 